Biogeosciences Discuss., 7, 9137-9173, 2010

www.biogeosciences-discuss.net/7/9137/2010/

doi:10.5194/bgd-7-9137-2010

(c) Author(s) 2010. CC Attribution 3.0 License.

Spatial and seasonal variability of soil respiration

\title{
Spatial and seasonal variability of heterotrophic and autotrophic soil respiration in a winter wheat stand
}

N. Prolingheuer, B. Scharnagl, A. Graf, H. Vereecken, and M. Herbst

Institute of Bio- and Geosciences, IBG-3: Agrosphere, Forschungszentrum Jülich, 52425 Jülich, Germany

Received: 2 December 2010 - Accepted: 5 December 2010 - Published: 15 December 2010 Correspondence to: N. Prolingheuer (n.prolingheuer@fz-juelich.de)

Published by Copernicus Publications on behalf of the European Geosciences Union.

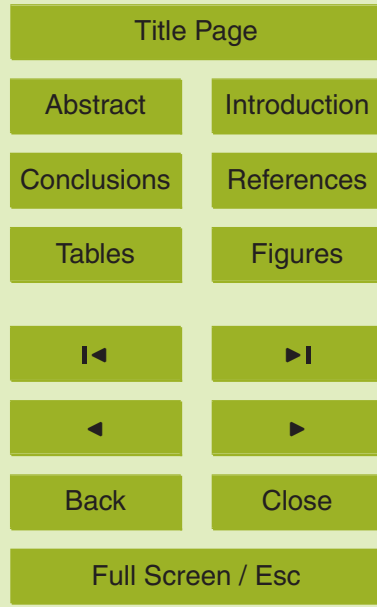

Printer-friendly Version

Interactive Discussion 


\section{Abstract}

Soil respiration $\left(R_{\mathrm{s}}\right)$, the sum of respiration by soil organisms $\left(R_{\mathrm{h}}\right)$ and roots $\left(R_{\mathrm{a}}\right)$, is known to be highly variable in both, space and time. There is less information available about the behaviour of $R_{\mathrm{h}}$ and $R_{\mathrm{a}}$ in time and particularly in space. The objective 5 of this study was to quantify the contribution of each component to the temporal and spatial variability of soil respiration in a winter wheat stand. We measured soil respiration from March to July 2009 by closed-dynamic chambers for 61 sampling points in a $50 \times 50 \mathrm{~m}$ plot in a winter wheat stand close to Jülich, Germany. Each sampling point was equipped with a $7 \mathrm{~cm}$ soil collar to measure total $R_{\mathrm{s}}$ and a $50 \mathrm{~cm}$ soil collar to exclude roots and to measure $R_{\mathrm{h}}$ only. $R_{\mathrm{a}}$ was assumed to equal $R_{\mathrm{s}}-R_{\mathrm{h}}$. Simultaneously, soil temperature and soil water content were measured in $6 \mathrm{~cm}$ depth. Biweekly the temporal development of the leaf area index was measured. On average, the heterotrophic contribution to $R_{\mathrm{s}}$ was $69 \%$ and thus higher than the autotrophic contribution. Seasonal changes of soil temperature and especially water content explained well the 15 temporal variability of $R_{\mathrm{s}}\left(r^{2}=0.74\right)$ and $R_{\mathrm{a}}\left(r^{2}=0.80\right)$. Spatial variability of $R_{\mathrm{a}}$ was on average much higher $(\mathrm{CV}=88 \%)$ than the spatial variability of $R_{\mathrm{h}}(\mathrm{CV}=30 \%)$. However, $R_{\mathrm{h}}$ was mainly randomly distributed in space, whereas $R_{\mathrm{a}}$ showed spatial autocorrelation. Spatial correlation and cross-variograms showed a significant spatial dependence of $R_{\mathrm{s}}$ on $R_{\mathrm{a}}$. From our results we concluded that spatial variability of soil respiration in a winter wheat stand represented mainly the spatial variability of the autotrophic component.

\section{Introduction}

The global atmospheric carbon concentration increased from a preindustrial value of 280 ppm to 379 ppm in 2005, mainly caused by the consumption of fossil fuels (IPCC, 2007). Soils, containing twice as much carbon as the atmosphere, could strongly change the carbon dioxide concentration in the atmosphere due to altered carbon losses (Smith et al., 2008).

BGD

7, 9137-9173, 2010

\section{Spatial and seasonal variability of soil respiration}

N. Prolingheuer et al.

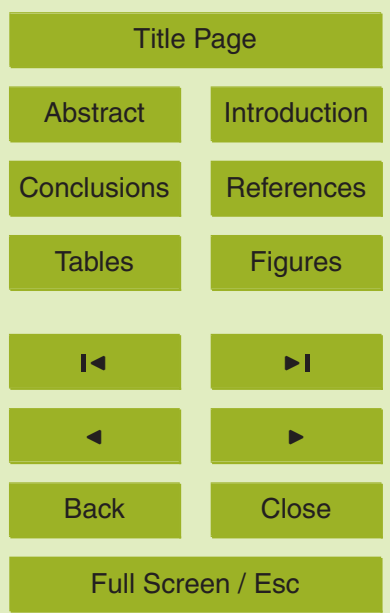

Printer-friendly Version

Interactive Discussion 
The emission of carbon dioxide from soils, usually referred to as soil respiration $\left(R_{\mathrm{S}}\right)$, is the second largest flux of carbon between terrestrial ecosystems and the atmosphere, constituting 20-38\% of the annual atmospheric input of $\mathrm{CO}_{2}-\mathrm{C}$ (Raich and Schlesinger, 1992). The sources of soil respiration are mainly of heterotrophic $\left(R_{\mathrm{h}}\right)$ and 5 autotrophic $\left(R_{\mathrm{a}}\right)$ nature:

$R_{\mathrm{s}}=R_{\mathrm{h}}+R_{\mathrm{a}}$

Microbial decomposition of soil organic matter represents the heterotrophic part, whereas the autotrophic part is the result of the metabolism of plant roots (Tang and Baldocchi, 2005). Here, we include the respiration of root exudates, e.g. by mycorrhizal funghi, to $R_{\mathrm{a}}$ despite the heterotrophic nature of these organisms (Andersen et al., 2005). This definition allows for a robust measurement methodology and is relevant for an adequate analysis of plant effects on spatial variability. The separation of $R_{\mathrm{s}}$ into its heterotrophic and autotrophic components remains an essential research challenge for the understanding and the modelling of the global carbon cycle and to estimate its response to climate change (Baggs, 2006). Different partitioning methods exist to separate $R_{\mathrm{s}}$ into $R_{\mathrm{h}}$ and $R_{\mathrm{a}}$ (Hanson et al., 2000). According to Kuzyakov (2006) they can be subdivided into two main groups: 1) non-isotopic methods, e.g. root-exclusion (e.g. Moyano et al., 2007) or model-based analysis of eddy-covariance measurements (e.g. Aubinet et al., 2009), and 2) isotopic methods, e.g. pulse labelling (e.g. Sapronov and 20 Kuzyakov, 2007) or bomb-derived ${ }^{14} \mathrm{C}$ (e.g. Gaudinski et al., 2000).

The proportions of $R_{\mathrm{h}}$ and $R_{\mathrm{a}}$ vary between ecosystems and crop types. For example Wang and Fang (2009) analysed 36 grassland data-sets and reported that on average $36 \%$ of $R_{\mathrm{s}}$ originates from autotrophic sources. For forest sites, the fraction of $R_{\mathrm{a}}$ varies between 5-90\% (Bond-Lamberty et al., 2004). At global scale, the autotrophic contribution to $R_{\mathrm{s}}$ varies between 10-90\% (Hanson et al., 2000).

The seasonal variability of $R_{\mathrm{s}}$ is mainly driven by soil temperature (e.g. Lloyd and Taylor, 1994; Davidson et al., 1998; Fang and Moncrieff, 2001; Davidson and Janssens, 2006) and to a lesser extent by soil water content (e.g. Davidson et al., 1998, 2000;
BGD

7, 9137-9173, 2010

\section{Spatial and seasonal variability of soil respiration}

N. Prolingheuer et al.



Printer-friendly Version

Interactive Discussion 
Tang et al., 2006; Almagro et al., 2009). The relation between soil temperature and soil respiration is often described by an exponential function (e.g. Lloyd and Taylor, 1994; Davidson et al., 1998). However, high temperatures in the summer can inhibit microbial activity and thus reduce soil respiration due to the mortal effect of soil temperatures 5 higher than $38^{\circ} \mathrm{C}$ (Fang and Moncrieff, 2001). An influence of soil water content on $R_{\mathrm{s}}$ is mainly observed during periods with extreme soil water contents (Reichstein et al., 2002; Borken et al., 2003). During droughts, microbial activity is inhibited due to the reduced water availability resulting in lower rates of $R_{\mathrm{h}}$. During wet periods the soil is almost saturated, which results on one hand in low concentrations of oxygen in the 10 soil inhibiting microbial activity and thus $R_{\mathrm{h}}$. On the other hand the transport of gases in the soil, e.g. carbon dioxide, is reduced inhibiting both $R_{\mathrm{h}}$ and $R_{\mathrm{a}}$. The relationship between soil water content and $R_{\mathrm{S}}$ can be described with a quadratic function (Qi and Xu, 2001; Sotta et al., 2004; Chang et al., 2008; Zimmermann et al., 2009).

Soil temperature and soil water content often control $R_{\mathrm{s}}$ not as independent but as 15 interacting variables. Droughts occur mainly in the summer season whereas soil water content is typically higher in the autumn and winter season. Apart from soil temperature and soil water content as abiotic factors, the temporal variability of the autotrophic component of $R_{\mathrm{s}}$ is mainly related to biotic factors, e.g. gross primary production (GPP), leaf area index and root biomass (Buchmann, 2000; Han et al., 2007; Bahn et al., 2008; Aubinet et al., 2009).

The spatial pattern of $R_{\mathrm{S}}$ is a mixture of the patterns of the heterotrophic and autotrophic component. $R_{\mathrm{a}}$ can increase the spatial variability of $R_{\mathrm{s}}$, if the root system adds heterogeneity, depending on the land use type. For example crops planted in rows, e.g. maize, reveal higher rates of $R_{\mathrm{s}}$ close to the rows due to the increased root 25 respiration (Rochette et al., 1991), adding a linear structure to the underlying structure of $R_{\mathrm{h}}$. A quite similar case is the soil respiration in forests, where the respiration is higher close to the stems, due to increasing root density (Tang and Baldocchi, 2005) and higher amounts of litter (Fang et al., 1998). However, there is no information in literature about the proportion of heterotrophic and autotrophic spatial variability on the

\section{BGD}

7, 9137-9173, 2010

\section{Spatial and seasonal variability of soil respiration}

N. Prolingheuer et al.

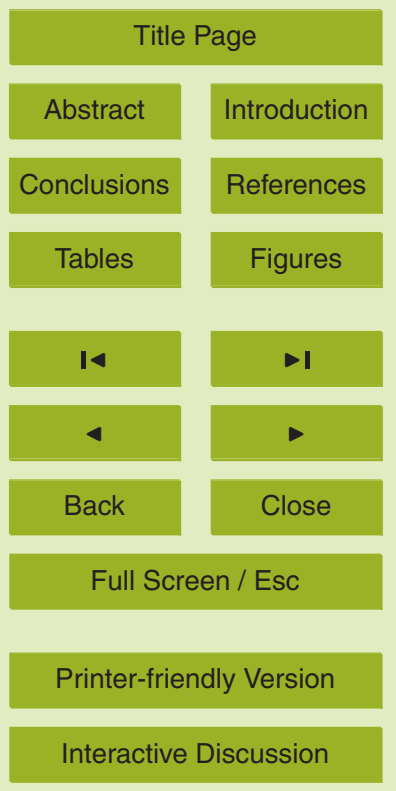


spatial variability of total $R_{\mathrm{s}}$.

The objectives of the study were (1) to analyse the contribution of heterotrophic and autotrophic respiration to the seasonal variability of $R_{\mathrm{s}},(2)$ to determine which of the two components, heterotrophic and autotrophic, mainly accounts for the spatial 5 variability of $R_{\mathrm{s}}$, and (3) to detect differences in the spatial correlation structure between the heterotrophic and the autotrophic component.

\section{Methods}

\subsection{Experimental site and climate conditions}

The experimental site (Fig. 1) was located in the agricultural area called "Jülicher

Börde" near Selhausen, approximately $7 \mathrm{~km}$ SE of Research Centre Jülich, Germany $\left(50^{\circ} 52^{\prime} 11^{\prime \prime} \mathrm{N}, 6^{\circ} 26^{\prime} 57^{\prime \prime} \mathrm{E}, 103 \mathrm{~m}\right.$ a.s.l.). The site is characterised by a temperate climate with an average annual temperature of $9.9^{\circ} \mathrm{C}$ and an average annual precipitation of $698 \mathrm{~mm}$. Sampling was done at a $50 \times 50 \mathrm{~m}$ plot within an agricultural field cultivated with winter wheat which was harvested on 27 July 2009. The soil type was a Haplic Luvisol according to the World Reference Base for Soil Resources (FAO, 2006). A detailed description of the soil is given by Weihermüller et al. (2007).

\subsection{Measurements}

Weekly measurements of soil respiration, soil temperature and soil water content were carried out between 19 March and 27 July 2009 within the $50 \times 50 \mathrm{~m}$ plot for 61 sampling locations, subdivided in 36 sample points located on a regular $10 \mathrm{~m}$ grid and 25 sample points randomly located in the $10 \times 10 \mathrm{~m}$ subplots (Fig. 1). Soil respiration was measured using an automatic closed dynamic chamber system (LI 8100-103, LI-COR Biosciences, Lincoln, Nebraska, USA). An adaption period of $1 \mathrm{~min}$ to achieve an ambient $\mathrm{CO}_{2}$ concentration inside the chamber-system was followed by a measurement
BGD

7, 9137-9173, 2010

\section{Spatial and seasonal variability of soil respiration}

N. Prolingheuer et al.

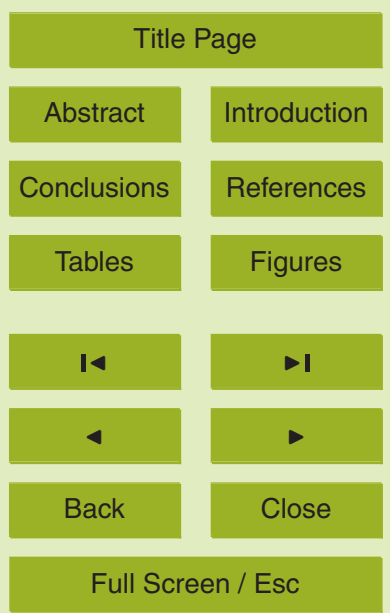

Printer-friendly Version

Interactive Discussion 
Permanently installed thermocouples were used to measure soil temperature $(T)$ at $6 \mathrm{~cm}$ depth within the soil collars. Permanently horizontally installed 3-rod TDR-probes with a rod-length of $20 \mathrm{~cm}$ were used to simultaneously measure soil water content $(\theta)$ in $6 \mathrm{~cm}$ depth inside the soil collars. Water content was calculated using Topp's 5 equation (Topp et al., 1980).

Green and brown leaf area index $\left(\mathrm{LAl}_{\mathrm{g}}, \mathrm{LAl}_{\mathrm{b}}\right)$ were measured bi-weekly at three locations in the wheat field with a portable leaf area meter (LI-3000A,LI-COR Biosciences, Lincoln, Nebraska, USA) and averaged.

\subsection{Partitioning of heterotrophic and autotrophic respiration}

10 In this study, the partitioning of $R_{\mathrm{h}}$ and $R_{\mathrm{a}}$ was done by root exclusion (Bowden et al., 1993; Hanson et al., 2000; Tang et al., 2005; Baggs, 2006; Subke et al., 2006; Moyano et al., 2007). Each sampling location consisted of one $7 \mathrm{~cm}$ and one $50 \mathrm{~cm}$ soil collar (PP-H, $20 \mathrm{~cm}$ diameter), close to each other, to measure $R_{\mathrm{s}}$ and $R_{\mathrm{h}}$, respectively. More than $80 \%$ of root biomass are located in the upper $50 \mathrm{~cm}$ of the soil (Wilhelm et al., collar and we assumed that the corresponding $\mathrm{CO}_{2}$ efflux represented $R_{\mathrm{h}}$. The $7 \mathrm{~cm}$ collars allowed a rooting inside the collar and we assumed that the corresponding $\mathrm{CO}_{2}$ efflux represents total $R_{\mathrm{s}}$. According to Eq. (1), $R_{\mathrm{a}}$ was calculated as the difference between $R_{\mathrm{s}}$ and $R_{\mathrm{h}}$. In the following, variables measured at locations of heterotrophic 20 soil respiration ( $50 \mathrm{~cm}$ soil collars) are indicated by subscript $\mathrm{h}$ and variables measured at locations of total soil respiration $(7 \mathrm{~cm}$ soil collars) are indicated by subscript $\mathrm{s}$.

\subsection{Soil temperature, water content and phenology controls on soil respiration}

The relationship between $R_{\mathrm{s}}$ and $T$ was modelled by an exponential function (Lloyd and Taylor, 1994):

$25 \quad R_{\mathrm{s}}=a e^{b T}$
BGD

7, 9137-9173, 2010

Spatial and seasonal variability of soil respiration

N. Prolingheuer et al.

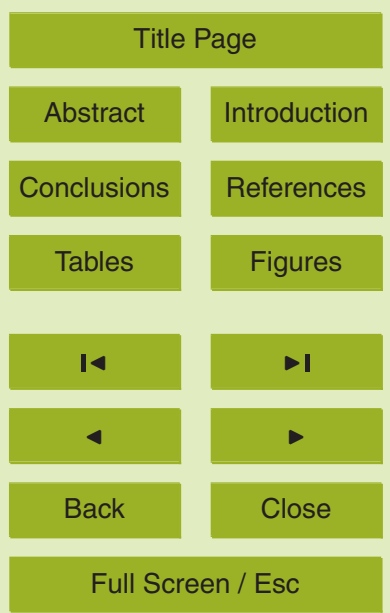

Printer-friendly Version

Interactive Discussion 
whith parameters $a$ and $b$. A potential function was used to model the relation between $R_{\mathrm{S}}$ and $\theta$ (Qi and $\mathrm{Xu}, 2001$ ):

BGD

$R_{\mathrm{s}}=a \theta^{c}$

with parameters $a$ and $c$. The dependence of $R_{\mathrm{s}}$ on LAI was described by a simple 5 linear function (Reichstein et al., 2003; Shi et al., 2006):

$R_{\mathrm{s}}=a+d \mathrm{LAI}$

with parameters $a$ and $d$. Equations (2) and (3) were then combined to model the relation between $R_{\mathrm{s}}, T$ and $\theta$ (Tang et al., 2006):

$R_{\mathrm{s}}=a e^{b T} \theta^{c}$

with parameters $a, b, c$. Equation (5) combined with Eq. (4) was used to additionally include the LAI:

$R_{\mathrm{s}}=a e^{b T} \theta^{c}+d \mathrm{LAl}$

with the additional parameter $d$. The differential evolution algorithm (Storn and Price, 1997) was used for model fitting. For model selection we calculated the Akaike infor15 mation criterion (AIC, Akaike, 1973, 1974):

$\mathrm{AIC}=-2 \ln L_{\text {Max }}+2 k$

where $\ln L_{\text {Max }}$ is the maximised log-likelihood function and $k$ is the number of fitted parameters. In case of a least squares estimation with normally distributed errors, the $\mathrm{AIC}$ is calculated using the sum of squares error of the fitted model:

$\mathrm{AIC}=n \ln \left(\frac{\sum_{i=1}^{n}\left(y_{\mathrm{obs}, i}-y_{\mathrm{est}, i}\right)^{2}}{n}\right)+2(k+1)$

where $n$ is the sample size and $y_{\text {obs }}$ and $y_{\text {est }}$ are the observed and estimated values. The equation uses $k+1$ instead of $k$ because the variance needs to be estimated. Due

\section{Spatial and seasonal variability of soil respiration}

N. Prolingheuer et al.

Title Page

Abstract

Introduction

Conclusions

References

Tables

Figures

14

4

Back

Close

Full Screen / Esc

Printer-friendly Version

Interactive Discussion 
to the small sample size in the present study $(n / k<40)$ we used the corrected Akaike information criterion $\left(\mathrm{AIC}_{\mathrm{c}}\right.$ ) proposed by Hurvich and Tsai (1989):

$\mathrm{AIC}_{\mathrm{C}}=\mathrm{AIC}+\frac{2(k+1)(k+2)}{n-k-2}$

Finally, the most suitable model is the one with the minimum $\mathrm{AIC}_{\mathrm{c}}$ value.

\subsection{Spatial analysis of states and fluxes}

Normal distribution of the data is a precondition for geostatistical analysis (Cressie and Hawkins, 1980) wherefore soil respiration data was log-transformed prior to spatial and temporal detrending and outlier detection. A temporal trend existed in the data due to the measurement duration of $3 \mathrm{~h}$ to sample the 61 locations. Respiration and temperature increased almost linearly over time since the measurements usually started at the morning and ended at noon. This temporal trend was removed by fitting a linear function to the data and detrending the data to the starting time. Due to the gentle slope in the plot (Fig. 1) a small linear spatial trend existed in the data which was removed by detrending the data to the same elevation. For detecting spatial outliers we used the basic Median Algorithm described by Chen et al. (2008) and extended it by a dynamic neighbour estimation and a spatial weighting of the neighbourhood function based on Kou et al. (2006). We chose a radius of $15 \mathrm{~m}$ for the dynamic neighbour estimation and $\alpha=0.05$ for the outlier criterion. At maximum 5 outliers per sampled dataset were detected and removed. The presence of outliers was mainly the result of erroneous

\subsubsection{Variogram estimation}

Geostatistical methods are common techniques to analyse spatial structure, behaviour and interactions of variables (Journel and Huijbregts, 1978; Goovaerts, 1998, 1999; Diggle and Ribeiro, 2007). Basic tool for the spatial analysis is the semivariogram

BGD

7, 9137-9173, 2010

\section{Spatial and seasonal variability of soil respiration}

N. Prolingheuer et al.



Printer-friendly Version

Interactive Discussion 
describing the spatial autocorrelation of a variable. The classical variogram estimator based on Matheron (1963) defines the semivariance $\gamma(h)$ as the mean squared difference between a set of data pairs for each specific lag distance $h$ :

$\gamma(h)=\frac{1}{2 N(h)} \sum_{i=1}^{N(h)}\left[z\left(x_{i}\right)-z\left(x_{i}+h\right)\right]^{2}$

5 where $N(h)$ is the number of data pairs in the given lag, $z\left(x_{i}\right)$ is the measured value at location $x_{i}$ and $z\left(x_{i}+h\right)$ is the measured value at location $x_{i}+h$. Due to the necessary log-normalisation of the soil respiration data a robust estimation of the semivariance following the approach of Cressie and Hawkins (1980) was applied:

$\gamma(h)=\frac{\left\{\frac{1}{|N(h)|} \cdot \sum_{i=1}^{N(h)}\left|Z\left(x_{i}\right)-Z\left(x_{i}+h\right)\right|^{1 / 2}\right\}^{4}}{2\left(0.457+\frac{0.494}{N(h)}\right)}$

10 where the constants 0.457 and 0.494 are based on the normality assumption.

Plotting the associated semivariance $\gamma(h)$ for each specific lag $h$ gives the sample variogram which could be fitted by models with three characteristic parameters: the nugget variance $c_{0}$, the structural variance $c_{1}$ and the range $a_{1}$. For estimating variogram parameters $c_{0}, c_{1}$ and $a_{1}$ we fitted a spherical model to the sample variogram:

${ }_{15} \gamma(h)= \begin{cases}c_{0}+c_{1}\left[\frac{1.5 h}{a_{1}}-0.5\left(\frac{h^{3}}{a_{1}}\right)\right] & \text { for } h \leq a_{1} \\ c_{0}+c_{1} & \text { for } h>a_{1}\end{cases}$

The nugget $c_{0}$ represents the sum of small-scale variability and measurement error. The structural variance $c_{1}$ represents spatial variability which exists inside range $a_{1}$. Therefore, the range $a_{1}$ is also referred to as spatial autocorrelation length. For distances larger than the range spatial autocorrelation is not given and semivariance
BGD

7, 9137-9173, 2010

Spatial and seasonal variability of soil respiration

N. Prolingheuer et al.

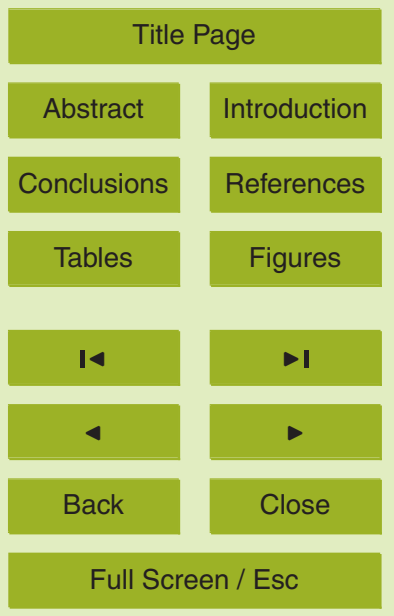

Printer-friendly Version

Interactive Discussion 
variability it is necessary to consider the magnitude of spatial dependence by calculating the nugget coefficient $n_{\mathrm{c}}$ (Robertson and Freckman, 1995; Morris, 1999; Hirobe et al., 2001; Mori and Takeda, 2003):

$n_{\mathrm{c}}=\frac{c_{0}}{c_{0}+c_{1}}$

5 where the nugget variance $c_{0}$ is related to the total variance $\left(c_{0}+c_{1}\right)$. If $n_{\mathrm{c}}$ is smaller than 0.25 the variable shows strong spatial dependence, if it varies between 0.25 and 0.75 there is only moderate spatial dependence and if $n_{\mathrm{c}}$ is larger than 0.75 there is basically no spatial dependence (Cambardella et al., 1994).

The spatial correlation between two variables $z_{i}$ and $z_{j}$ and their variation in space 10 is given by the cross-semivariance:

$\gamma_{i, j}(h)=\frac{1}{2 N(h)} \sum_{\alpha=1}^{N(h)}\left[z_{i}\left(x_{\alpha}\right)-z_{i}\left(x_{\alpha}+h\right)\right]\left[z_{j}\left(x_{\alpha}\right)-z_{j}\left(x_{\alpha}+h\right)\right]$

Again, the differential evolution algorithm (Storn and Price, 1997) was used to fit the spherical model to the sample variogram. Robust variogram estimation and spherical model fitting were implemented in GNU Octave (Eaton, 2002). Cross-variograms were calculated using the variogram-function of the gstat-package (Pebesma, 2004) in the $R$-environment (R Development Core Team, 2005). To calculate an average range of spatial autocorrelation, we selected measurement dates for which the following two criteria applied: i) the coefficient of determination $\left(r^{2}\right)$ between the sample variogram and the fitted spherical model function was higher than 0.5 to avoid the impact of erroneous variogram fittings on the average range estimate. ii) the nugget coefficient $\left(n_{\mathrm{c}}\right)$ was lower than 0.75 to ensure at least a moderate spatial dependence.

\subsubsection{Spatial mapping of states and fluxes}

Compared to kriging as an estimation approach, simulation approaches focus on the reproduction of the statistics and geostatistics of the observation, e.g. histogram and 9146
BGD

7, 9137-9173, 2010

Spatial and seasonal variability of soil respiration

N. Prolingheuer et al.

Title Page

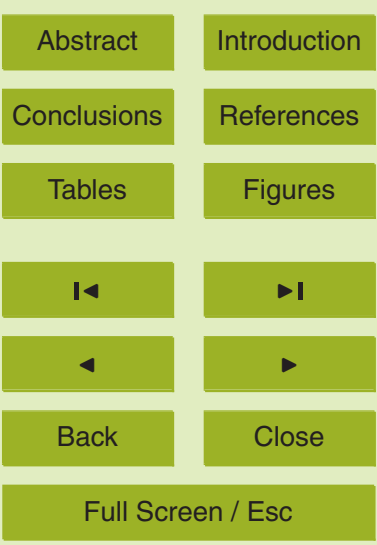

Printer-friendly Version

Interactive Discussion 
variogram (Goovaerts, 1999). Conditional sequential Gaussian simulation (SGS, Rossi et al., 1993; Goovaerts, 2000; King, 2000) was used for mapping the spatial pattern of soil respiration. A simulation is conditioned when it reproduces measured data at measured locations. The basic steps of SGS are well descripted by Deutsch and 5 Journel (1998); King (2000); Goovaerts (2001). SGS was done using the krige-function of the gstat-package (Pebesma, 2004). The simulated fields included 2000 nodes and we generated 100 realizations for each simulated data set. From this, the realisation was chosen which best reproduced the statistics of the observation.

\section{Results and discussion}

\subsection{Seasonal variation of total, heterotrophic and autotrophic soil respiration}

During the measurement period between 19 March and 27 July 2009, $R_{\mathrm{s}}$ was on average $2.68 \pm 0.98 \mu \mathrm{mol} \mathrm{m} \mathrm{m}^{-2} \mathrm{~s}^{-1}$. The standard deviation represents the standard deviation of the field mean during the season. $R_{\mathrm{s}}$ showed a characteristic seasonal variation (Fig. 2a) and ranged between $1.06 \pm 0.49 \mu \mathrm{mol} \mathrm{m} \mathrm{m}^{-2} \mathrm{~s}^{-1}$ and $5.04 \pm 3.03 \mu \mathrm{mol} \mathrm{m}^{-2} \mathrm{~s}^{-1}$. 15 Between March and the middle of May $R_{\mathrm{S}}$ increased and showed the maximum on 15 May when also the $\mathrm{LAl}_{\mathrm{g}}$ of winter wheat was highest (Fig. 2e). After plant senescence, $R_{\mathrm{s}}$ decreased and fluxes of about $2.5 \mu \mathrm{mol} \mathrm{m} \mathrm{m}^{-2} \mathrm{~s}^{-1}$ were measured. $R_{\mathrm{h}}$ was rather constant during the measurement period with an overall average of $2.07 \pm 0.38 \mu \mathrm{mol} \mathrm{m}{ }^{-2} \mathrm{~s}^{-1}$. Compared to $R_{\mathrm{s}}$, the seasonal variation of $R_{\mathrm{h}}$ was smaller and ranged between $1.32 \pm 0.34 \mu \mathrm{mol} \mathrm{m}^{-2} \mathrm{~s}^{-1}$ and $2.81 \pm 1.03 \mu \mathrm{mol} \mathrm{m} \mathrm{m}^{-2} \mathrm{~s}^{-1}$. As expected, after plant senescence for the last three sampling dates in July $R_{\mathrm{h}}$ was equal to $R_{\mathrm{s}}$. The seasonal variation of $R_{\mathrm{a}}$ was equal to the seasonal variation of $R_{\mathrm{s}}$. Compared to $R_{\mathrm{h}}$ the average flux of $R_{\mathrm{a}}$ was smaller with $0.93 \pm 0.82 \mu \mathrm{mol} \mathrm{m}^{-2} \mathrm{~s}^{-1}$ and showed fluxes up to $2.59 \pm 1.48 \mu \mathrm{mol} \mathrm{m}{ }^{-2} \mathrm{~s}^{-1}$ (22 April).
BGD

7, 9137-9173, 2010

\section{Spatial and seasonal variability of soil respiration}

N. Prolingheuer et al.

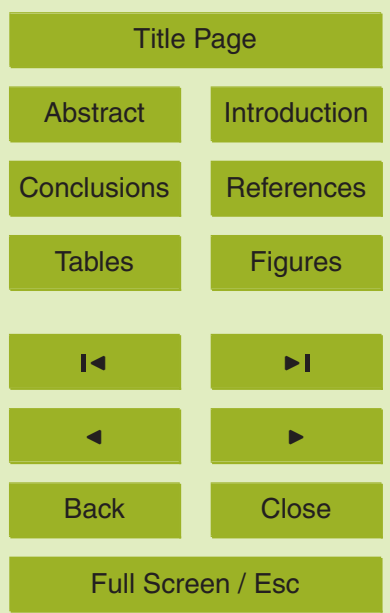

Printer-friendly Version

Interactive Discussion 
Several studies on soil respiration in winter wheat focused on total $R_{\mathrm{s}}$ rather than on the single contributions of $R_{\mathrm{h}}$ and $R_{\mathrm{a}}$. Beyer (1991) measured $R_{\mathrm{s}}$ in winter wheat from June to December 1986 at two sites in Schleswig-Holstein, Germany. He also observed a characteristic increase of $R_{\mathrm{s}}$ during the summer and a decrease during au5 tumn and winter. However, their measured fluxes of $R_{\mathrm{s}}$ were smaller with a maximum of around $2 \mu \mathrm{mol} \mathrm{m} \mathrm{m}^{-2} \mathrm{~s}^{-1}$ in August, which might be attributed to lower temperatures during summer and to a lower organic carbon content of the soil. $R_{\mathrm{s}}$ measured by Rochette et al. (1991) from May to August 1989 in a spring wheat field in Ottawa, Kanada, was higher with an average efflux of $6.5 \mu \mathrm{mol} \mathrm{m} \mathrm{m}^{-2} \mathrm{~s}^{-1}$ and ranged between $2.7 \mu \mathrm{mol} \mathrm{m}{ }^{-2} \mathrm{~s}^{-1}$ 10 and $11.9 \mu \mathrm{mol} \mathrm{m}^{-2} \mathrm{~s}^{-1}$. However, soil temperature was much higher during the season ranging between $20^{\circ} \mathrm{C}$ and $33^{\circ} \mathrm{C}$ from June to September. Comparable fluxes of $R_{\mathrm{s}}$ were measured by Moureaux et al. (2008) in a wheat plot in Belgium in 2005. Their measured fluxes ranged between 2 and $3 \mu \mathrm{mol} \mathrm{m} \mathrm{m}^{-2} \mathrm{~s}^{-1}$ from May to August 2005.

The strong decrease of $R_{\mathrm{s}}$ and $R_{\mathrm{a}}$ on 5 May may have two reasons. On one hand, 15 this might be the result of reduced photosynthetic activity of the plants due to an overcast sky. On the other hand, also soil water content showed a clear decrease (Fig. 2d) which probably caused stress on root activities and inhibited root respiration as reported by Epron et al. (1999); Rey et al. (2002); Saiz et al. (2006).

The autotrophic contribution to total soil respiration (Fig. 2b) was highest in April with 20 $60 \%$ and decreased to almost zero at plant senescence. During June the autotrophic contribution increased up to a seccond maximum of $40 \%$ and decreased afterwards down to zero at the middle of July when only heterotrophic respiration occured. This needs to be seen against the background of the temporal spacing of the measurement dates because they allow to track the seasonal development of respiration, but of not the short-time variations occurring between the measurement dates. Cumulated values of $R_{\mathrm{s}}, R_{\mathrm{h}}$ and $R_{\mathrm{a}}$ between April and August were $342 \mathrm{~g} \mathrm{C} \mathrm{m}^{-2}, 236 \mathrm{~g} \mathrm{C} \mathrm{m}^{-2}$ and $106 \mathrm{~g} \mathrm{C} \mathrm{m}^{-2}$, respectively, equivalent to relative contributions of $69 \%$ for $R_{\mathrm{h}}$ and $31 \%$ for $R_{\mathrm{a}}$. The study by Moureaux et al. (2008) reported cumulative $R_{\mathrm{s}}, R_{\mathrm{h}}$ and $R_{\mathrm{a}}$ from November 2004 to July 2005 of $520 \mathrm{~g} \mathrm{C} \mathrm{m}^{-2}, 230 \mathrm{~g} \mathrm{C} \mathrm{m}^{-2}$ and $290 \mathrm{~g} \mathrm{C} \mathrm{m}^{-2}$,

\section{BGD}

7, 9137-9173, 2010

\section{Spatial and seasonal variability of soil respiration}

N. Prolingheuer et al.

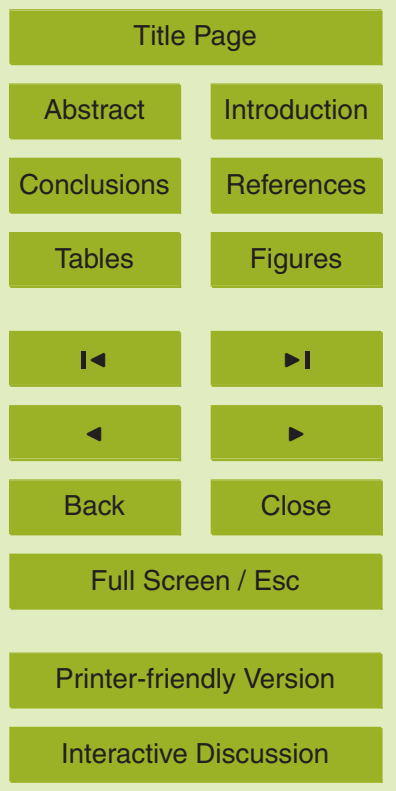

Interactive Discussion 
respectively. The resultant autotrophic contribution to $R_{\mathrm{s}}$ was $56 \%$. Shi et al. (2006) modelled $R_{\mathrm{s}}$ and $R_{\mathrm{h}}$ in the growing season by two temperature functions valid for the growing and non-growing season, respectively. From the difference between modelled $R_{\mathrm{S}}$ and $R_{\mathrm{h}}$ they calculated $R_{\mathrm{a}}$ and found an autotrophic contribution of $45 \%$. The lower 5 average contributions of $R_{\mathrm{a}}$ we detected could be explained by the fact that at the beginning of the measurements significant contributions of $R_{\mathrm{a}}$ were already observed an no measurements of $R_{\mathrm{a}}$ were performed in the early growing period.

Significant differences in soil water content between the neighbouring soil collars were observed during the study (Fig. 2d). It was to be expected that these water 10 content differences were caused by root water uptake in the $7 \mathrm{~cm}$ soil collars which lead to lower water contents in the $7 \mathrm{~cm}$ collars. Right at the beginning of the growing season, when the root system of the plants was in the starting phase of development, lower water contents in the $50 \mathrm{~cm}$ collars were detected. This could partly be explained by installation effects of the TDR-probes in the $50 \mathrm{~cm}$ collars, e.g. the rods of the probes

15 were not fully in contact with the soil when installing them through the collar, leading to an underestimation of the water contents. At the end of May, the influence of root water uptake in the $7 \mathrm{~cm}$ collars was clearly detected, which caused lower water contents in the $7 \mathrm{~cm}$ soil collars.

\subsection{Soil temperature, water content and phenology controls on soil respiration}

20 The seasonal variation of soil respiration is mainly controlled by soil temperature changes (e.g. Lloyd and Taylor, 1994; Buchmann, 2000; Fang and Moncrieff, 2001; Reichstein et al., 2002; Subke et al., 2003; Reichstein et al., 2005; Davidson and Janssens, 2006; Savage et al., 2009) and are commonly described by an exponential function. A slightly negative relation between soil respiration and soil temperature 25 was found in our study (Tables 1 and 2). This may be attributed to two reasons. First, the data set just represents 18 snapshots of the seasonal change of soil respiration. Second, other environmental drivers including moisture and plant development status as studied here, may act as confounding factors (Davidson et al., 1998). Analysing the

BGD

7, 9137-9173, 2010

\section{Spatial and seasonal variability of soil respiration}

N. Prolingheuer et al.

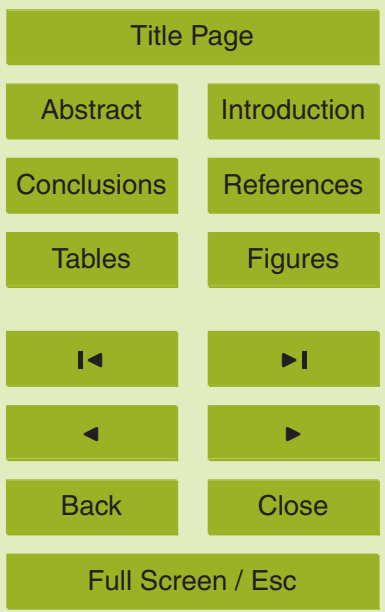

Printer-friendly Version

Interactive Discussion 
residuals of the temperature model (Eq. 2) showed a positive linear relation between $\theta$ and $R_{\mathrm{s}}, R_{\mathrm{h}}$ and $R_{\mathrm{a}}$ with $r^{2}=0.71, r^{2}=0.38$ and $r^{2}=0.71$, respectively. This water content influence is expressed by a significant positive correlation between soil respiration and water content (Table 1), which was highest for $R_{\mathrm{a}}$ with $r=0.80(p<0.001)$ in 5 combination with a negative correlation between soil temperature and water content, which was significant for $T_{\mathrm{s}}$ and $\theta_{\mathrm{s}}$ with $r=-0.69(p<0.01)$. Using soil water content to model the temporal behaviour of soil respiration (Eq. 3) resulted in a higher $r^{2}$ and a lower RMSE compared to the temperature model. Also the $\mathrm{AIC}_{\mathrm{c}}$ decreased significantly and points to a more suitable model. Studies by e.g., Davidson et al. (1998); 10 Borken et al. (2003); Savage and Davidson (2003); Martin and Bolstad (2005); Almagro et al. (2009); Herbst et al. (2009) also reported a strong influence of soil water content on soil respiration. Soil temperature and soil water content were negatively correlated because warm temperatures in summer are often accompanied by low soil water contents, whereas in winter, cold temperatures are accompanied by high soil 15 water content values. Indeed, the full models considering all available explanatory variables yield temperature exponents of 0.005 and 0.026 for $R_{\mathrm{h}}$ and $R_{\mathrm{s}}$, respectively. These would translate into $Q_{10}$ values of 1.05 and 1.30. The unusual low value for $R_{\mathrm{h}}$ can clearly be attributed to the extremely high scatter of the relation between soil temperature and $R_{\mathrm{h}}$, which forces the slope of a regression model to underestimate 20 full $R_{\mathrm{s}}$ model may in part be attributed to the same reason, but may also be taken as a support of a recent study suggesting lower temperature sensitivities of respiration than previously (Mahecha et al., 2010). Only $R_{\mathrm{a}}$ exhibits a negative temperature exponent even after considering soil water content and LAI. It is still debated whether root respiration is positively affected by temperature at all (Moyano et al., 2007).

Adding soil water content as an explanatory variable to the temperature model using Eq. (5) resulted in better estimates of $R_{\mathrm{s}}$ and $R_{\mathrm{a}}$, however, not of $R_{\mathrm{h}}$ (Table 2, Fig. 3a-c). The relation of $R_{\mathrm{s}}$ and $R_{\mathrm{a}}$ with soil temperature and soil water content were significant $(p<0.001)$ and explained $74 \%$ and $80 \%$, respectively, of the seasonal variability of soil

\section{BGD}

7, 9137-9173, 2010

\section{Spatial and seasonal variability of soil respiration}

N. Prolingheuer et al.

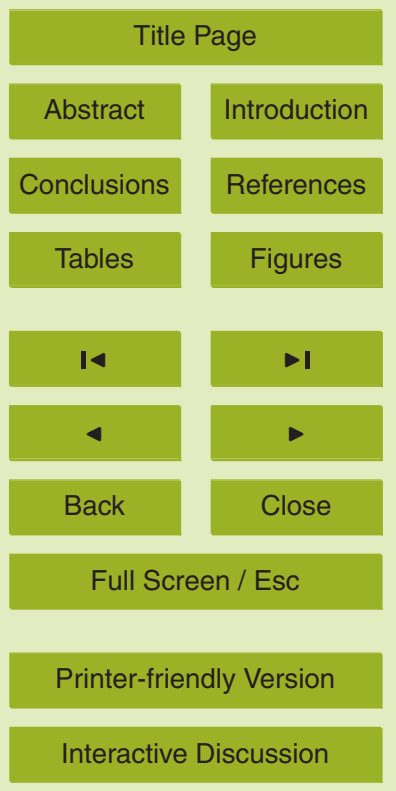

Interactive Discussion 
respiration. Similar coefficients of determination were reported by Tang et al. (2006) for explaining the seasonal variability of $R_{\mathrm{s}}$ by changes of soil temperature and soil water content in subtropical forests in Southern China. Similar to their findings our results indicate that accounting for both, temperature and water content, provided a more 5 suitable model in terms of $\mathrm{AIC}_{\mathrm{c}}$ compared to just accounting for either temperature or water content. Only $27 \%$ of the seasonal variability of $R_{\mathrm{h}}$ could be explained by temperature and water content which was similar to model $R_{\mathrm{h}}$ in dependence of water content only. Thus, modelling $R_{\mathrm{h}}$ with water content only was more suitable due to the smaller $\mathrm{AIC}_{\mathrm{C}}$.

10 Autotrophic respiration is likely also a function of the development status of the plant and its root system. As an easily accessible indicator of plant developement status, LAI may be related to root respiration via a linear model (Reichstein et al., 2003, Eq. 4). In our case, $R_{\mathrm{s}}$ and $R_{\mathrm{a}}$ showed only a weak relation with $\mathrm{LAl}_{\mathrm{g}}$ having coefficients of determination of 0.38 and 0.21 , respectively (Table 2). This corroborates the findings of 15 Hibbard et al. (2005) who analysed soil respiration from various Northern Hemisphere temperate ecosystems. They explained it by large variations in the autotrophic contributions to total $R_{\mathrm{s}}$, which was also observed in our measurements (Fig. 2b). This was quite different to the findings of Reichstein et al. (2003) and Shi et al. (2006). They explained $83 \%$ and $69 \%$, respectively, of the seasonal variations of $R_{\mathrm{s}}$ by temporal changes in $\mathrm{LAI}_{\mathrm{g}}$. This discrepancy might simply be explained by the extended observation period and the higher temporal resolution of the respiration measurements compared to our data.

Due to the rather weak relation between $R_{\mathrm{s}}$ and $R_{\mathrm{a}}$ with $\mathrm{LAI}_{\mathrm{g}}$ and compared to the modelling without $\mathrm{LAl}_{\mathrm{g}}$ the additional parameter explained only slightly more of the 25 seasonal variability in $R_{\mathrm{s}}$ and $R_{\mathrm{a}}\left(r^{2}=0.77\right.$ and $r^{2}=0.81$, respectively). The increase of $17 \%$ and $19 \%$ for $R_{\mathrm{s}}$ and $R_{\mathrm{a}}$, respectively, in terms of the $\mathrm{AIC}_{\mathrm{c}}$ was higher than the decrease in the RMSE with $7 \%$ and $1 \%$ for $R_{\mathrm{s}}$ and $R_{\mathrm{a}}$, respectively. Including the $\mathrm{LAI}_{\mathrm{g}}$ to estimate $R_{\mathrm{s}}$ and $R_{\mathrm{a}}$ did not provide a more suitable model.
BGD

7, 9137-9173, 2010

\section{Spatial and seasonal variability of soil respiration}

N. Prolingheuer et al.

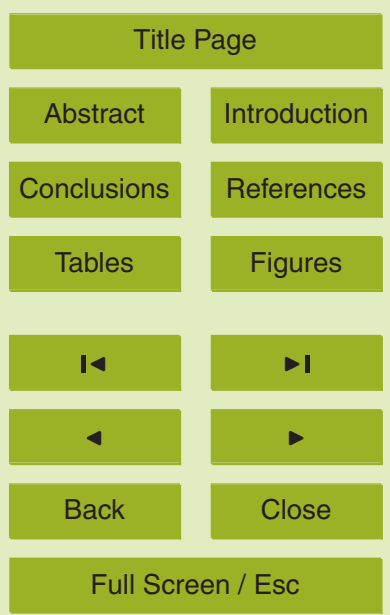

Printer-friendly Version

Interactive Discussion 


\subsection{Seasonal development of spatial variations}

The standard deviation shows the similarity in the seasonal trend of the spatial variations of $R_{\mathrm{s}}$ and $R_{\mathrm{a}}$ (Fig. 4a). The autotrophic contribution to the spatial variations of $R_{\mathrm{s}}$ (Fig. 4b) was highest at the beginning of the growing season with relative contributions 5 up to $90 \%$. Afterwards the autotrophic contribution decreased linearly $\left(r^{2}=0.67\right)$ and at the beginning of June the autotrophic and the heterotrophic contribution to the spatial variation of $R_{\mathrm{s}}$ were similar. In the following period the heterotrophic contribution dominated and increased until harvest. Considerably higher spatial variations of $R_{\mathrm{a}}$ mainly caused the spatial variations in total $R_{\mathrm{s}}$ (Fig. $4 \mathrm{a}, \mathrm{b}$ ).

10 The temporal trend of the spatial variations in terms of the coefficient of variation (CV) was also quite similar for $R_{\mathrm{s}}, R_{\mathrm{h}}$ and $R_{\mathrm{a}}$ (Fig. 4c), except for the peak in $R_{\mathrm{a}}$ on 6 June $(\mathrm{CV}=502 \%)$ caused by a short drought period existing from the middle of May up to the beginning of June with subsequent rewetting just before the measurement (Fig. 2d). A second peak of spatial variation was observed on 15 July for the autotrophic component because the wheat was nearly ripened and at various locations $R_{\mathrm{a}}$ was close to zero. The coefficient of variation relates the standard deviation to the average. The very low average fluxes of $R_{\mathrm{a}}$ observed at 6 June and 15 July combined with rather mid-range standard deviations (Fig. 4a) therefore resulted in two extreme coefficients of variation. During the observation period such average fluxes close to zero were not detected for $R_{\mathrm{h}}$. During the growing season the CV was on average much higher for $R_{\mathrm{a}}(\mathrm{CV}=118 \%)$ than for $R_{\mathrm{h}}(\mathrm{CV}=30 \%)$. Excluding the two extremes reveals a lower $\mathrm{CV}$ of $88 \%$ for $R_{\mathrm{a}}$. Spatial variations of $R_{\mathrm{a}}$ decreased very slightly during April and increased until the middle of May caused by plant growth. Stoyan et al. (2000) reported high spatial variations in root weights of wheat at a $2 \mathrm{~m}^{2}$ plot which were higher in between root weight and $R_{\mathrm{s}}$ which was on average 0.63. A general pattern might exist for cropped systems with lower spatial variations of $R_{\mathrm{s}}$ at the beginning of plant growth when the root-system is not fully developed and higher variations at full-grown stage since it was also detected for maize (Han et al., 2007).

BGD

7, 9137-9173, 2010

\section{Spatial and seasonal variability of soil respiration}

N. Prolingheuer et al.



Interactive Discussion 
A similar temporal behaviour was observed for total $R_{\mathrm{s}}$ even though less pronounced (Fig. 4c), because of the rather time-stable heterotrophic contribution. The average CV for $R_{\mathrm{s}}$ was $38 \%$. Rochette et al. (1991) measured a similar spatial variability of $R_{\mathrm{s}}$ on a 26 ha wheat field in Canada with an average CV of $45 \%$. In contrast, they 5 found a clear decrease of the spatial variations during the growing season from the beginning of May to the middle of August caused by an uneven application of solid manure in May. Solid manure was not applied in our study. Less spatial variation of $R_{\mathrm{h}}$ compared to $R_{\mathrm{a}}$ may result from a more heterogeneous root distribution compared to a more homogeneous distribution of microbes and carbon. Katsalirou et al. (2010) 10 found relatively low spatial variations of microbial biomass ( $C V=28 \%)$ at a 2-m transect $(0.2 \mathrm{~m}$ intervals) in a wheat field in the Southern Great Plains, USA.

\subsection{Spatial structure of soil respiration}

The variogram analysis revealed differences in the spatial structures of $R_{\mathrm{h}}$ and $R_{\mathrm{a}}$ (Table 3). For $R_{\mathrm{h}}$ the nugget coefficient was larger than 0.75 for 12 out of 18 dates, pointing to a poor spatial autocorrelation in $R_{\mathrm{h}}$. At 9 measurement dates the variogram showed a pure nugget effect indicating a random distribution of $R_{\mathrm{h}}$ in space. A minimum nugget coefficient of 0.03 for $R_{\mathrm{h}}$ was detected on 22 July. The predominantly random spatial structure of $R_{\mathrm{h}}$ was also detected by Rochette et al. (1991) and Herbst et al. (2009) for bare soil plots. Herbst et al. (2009) found an average $n_{c}$ of 0.71 for 15 20 sampling dates between April and July 2007 at a $14 \times 14 \mathrm{~m}$ bare plot. Rochette et al. (1991) detected a predominantly random structure of $R_{\mathrm{h}}$ at two bare fields of 25 and 40 ha. The reason for the predominantly random structure of $R_{\mathrm{h}}$ might be the smallscale spatial variability of the microbial communities and carbon pools (Nunan et al., 2002). However, it should also be seen against the background of the lower coefficient of variation compared to $R_{\mathrm{a}}$ and thus a larger influence of a potential error variance.

In contrast to $R_{\mathrm{h}}$, we detected a moderate to strong spatial dependence of $R_{\mathrm{a}}$. The $n_{\mathrm{c}}$ of $R_{\mathrm{a}}$ was smaller than 0.75 at 14 of the 18 measurement dates, 7 dates showed an $n_{\mathrm{c}}<0.25 . R_{\mathrm{s}}$ showed predominantly moderate or no spatial dependence with $n_{\mathrm{c}}>0.25$
BGD

7, 9137-9173, 2010

\section{Spatial and seasonal variability of soil respiration}

N. Prolingheuer et al.

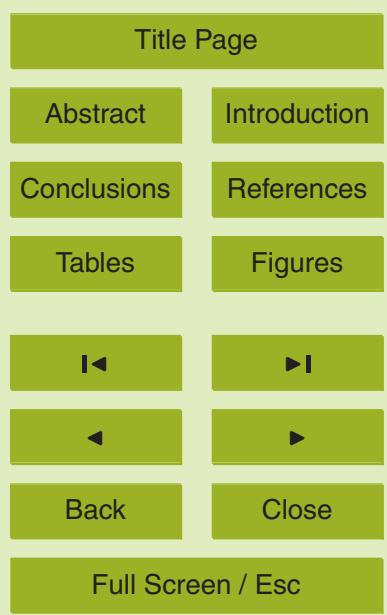

Printer-friendly Version

Interactive Discussion 
(18 of 20 dates). At two dates (5 May and 15 July) a strong spatial dependence with $n_{\mathrm{c}}<0.25$ was detected.

Cambardella et al. (1994) and Goovaerts (1998) pointed out that spatial autocorrelation is linked with a strong scale dependence. Western and Blöschl (1999) showed 5 that the apparent correlation length increases with increasing spacing between sample points, extent of the observation area and sampling volume referred to as "support". The apparent variance increases with increasing extent, decreases with increasing support and is constant for different spacings. We operated with a support of $0.031 \mathrm{~m}^{2}$, an average spacing of $4.61 \mathrm{~m}$ and an extent of $50 \times 50 \mathrm{~m}$. In case spatial dependence 10 was detected, defined by $n_{c}<0.75$ and $r^{2} \geq 0.5$ of variogram model fit, the average range of spatial autocorrelation $\left(a_{1}\right)$ of $R_{\mathrm{h}}$ was $11 \mathrm{~m}$ at the observed scale. Herbst et al. (2009) reported an average range of spatial autocorrelation of $2.7 \mathrm{~m}$ for $R_{\mathrm{h}}$ for an extent of $14 \times 14 \mathrm{~m}$. Rochette et al. (1991) detected for $R_{\mathrm{h}}$ a correlation length of $20 \mathrm{~m}$ for one of their 1-m spacing transects. For $R_{\mathrm{a}}$ and $R_{\mathrm{s}}$ we observed an almost 15 similar average range of spatial autocorrelation of $16.8 \mathrm{~m}$ and $18.0 \mathrm{~m}$, respectively, being larger than the average range of $R_{\mathrm{h}}$ with $11 \mathrm{~m}$. Stoyan et al. (2000) measured $R_{\mathrm{s}}$ in winter wheat and reported a range of spatial autocorrelation of $29 \mathrm{~cm}$ for a clearly smaller support of $1.76 \times 10^{-4} \mathrm{~m}^{2}$ and an extent of $2 \mathrm{~m}^{2}$. Due to the smaller support of their sampling the detected spatial variation of $R_{\mathrm{s}}$ was higher compared to our findings.

20 The authors attributed this to "hot- and cold-spots" of very high and low soil respiration rates that often lied within the sampling volume (Morris, 1999).

The simulated maps of $R_{\mathrm{s}}, R_{\mathrm{h}}$ and $R_{\mathrm{a}}$ shown for the measurements on 5 May and 28 May (Fig. 5a-h) represent typical spatial patterns. The variograms (Fig. 5a,e) revealed highest spatial variations for the autotrophic component. $R_{\mathrm{a}}$ showed strong 25 spatial dependence $\left(n_{\mathrm{c}}=0\right)$, whereas $R_{\mathrm{h}}$ is totally random distributed in space showing a pure nugget. This caused a strong (5 May) and moderate (28 May) spatial dependence of $R_{\mathrm{S}}$ as a mixture of the autotrophic and heterotrophic pattern. The ranges of spatial autocorrelation for $R_{\mathrm{a}}$ and $R_{\mathrm{s}}$ were $13.7 \mathrm{~m}$ and $7.4 \mathrm{~m}$, respectively, on 5 May. On 28 May ranges were $7.5 \mathrm{~m}$ and $10.5 \mathrm{~m}$, respectively, being shorter than the respective

BGD

7, 9137-9173, 2010

\section{Spatial and seasonal variability of soil respiration}

N. Prolingheuer et al.

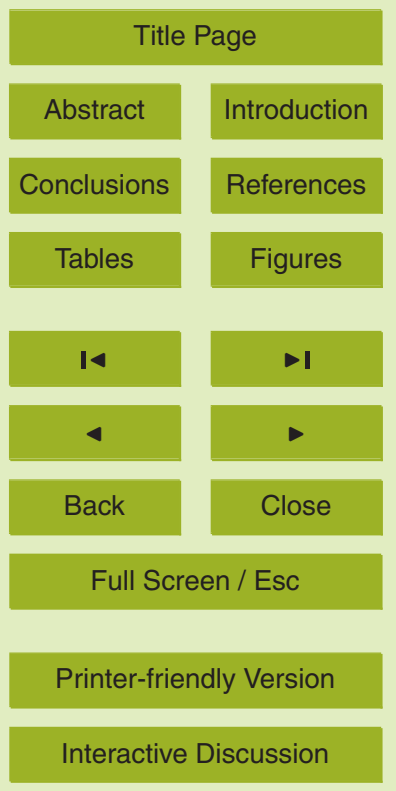

Interactive Discussion 
average range of spatial autocorrelation detected in our data. In contrast to spatial structures in the maps of $R_{\mathrm{a}}$ and $R_{\mathrm{s}}$, the map of $R_{\mathrm{h}}$ represents random noise. The third mapping of $R_{\mathrm{s}}, R_{\mathrm{h}}$ and $R_{\mathrm{a}}$ shown for the measurements on 20 May (Fig. 5j-l) represents a rather exceptioned state of spatial autocorrelation. Variograms showed 5 that the nugget of $R_{\mathrm{s}}$ with $0.26, R_{\mathrm{h}}$ with 0.34 and $R_{\mathrm{a}}$ with 0.10 were quite similar indicating moderate spatial dependence also for $R_{\mathrm{h}}$. There were differences in the range of spatial autocorrelation with the highest range of $24 \mathrm{~m}$ detected for $R_{\mathrm{a}}$, followed by $R_{\mathrm{s}}$ with $19 \mathrm{~m}$ and $R_{\mathrm{h}}$ with $9 \mathrm{~m}$. Consequently, the spatial pattern of $R_{\mathrm{h}}$ again reveals a more random characteristic than the patterns of $R_{\mathrm{s}}$ and $R_{\mathrm{a}}$. Due to the spatially ho10 mogeneous planting of winter wheat characteristic row-interrow patterns detected by Rochette et al. (1991) as a result of higher fluxes close to the rows, were not observed. Nevertheless, the autotrophic component showed high spatial variations and a clear spatial dependence which might be attributed to e.g. heterogeneity in the root system. To detect the source of the spatial structure of $R_{\mathrm{a}}$ in winter wheat spatial information about e.g. LAl and root density is needed.

As shown before, the spatial variation of $R_{\mathrm{s}}$ was mainly influenced by the autotrophic spatial variations. The spatial distribution of $R_{\mathrm{s}}$ was highly correlated with the spatial distribtuion of $R_{\mathrm{a}}$ (Fig. 6a). At the beginning of the growing season the coefficient of correlation in space was highest between $R_{\mathrm{s}}$ and $R_{\mathrm{a}}$ with $r=0.80$ and was almost constant until the middle of May. Afterwards the spatial correlation fluctuantly decreased to values of about 0.55 due to the decrease of autotrophic contributions to $R_{\mathrm{s}}$ as a result of plant senescence. Generally, the spatial pattern in $R_{\mathrm{s}}$ was stronger correlated to $R_{\mathrm{a}}$ than to $R_{\mathrm{h}}$. The spatial correlation between $R_{\mathrm{s}}$ and $R_{\mathrm{h}}$ was lowest at the beginng of the growing season ranging between 0 and 0.20 and increased towards the end of the growing season when values ranged between 0.20 and 0.40 .

Cross-variograms were calculated to analyse the spatial cross-correlation of $R_{\mathrm{s}}$ with $R_{\mathrm{h}}$ and $R_{\mathrm{a}}$, respectively. The cross-variograms predominantly revealed a clear spatial dependence of $R_{\mathrm{s}}$ from $R_{\mathrm{a}}$ whereas the cross-variograms between $R_{\mathrm{s}}$ and $R_{\mathrm{h}}$ showed predominantly pure nuggets and thus no spatial cross-correlation. As an example,
BGD

7, 9137-9173, 2010

\section{Spatial and seasonal variability of soil respiration}

N. Prolingheuer et al.

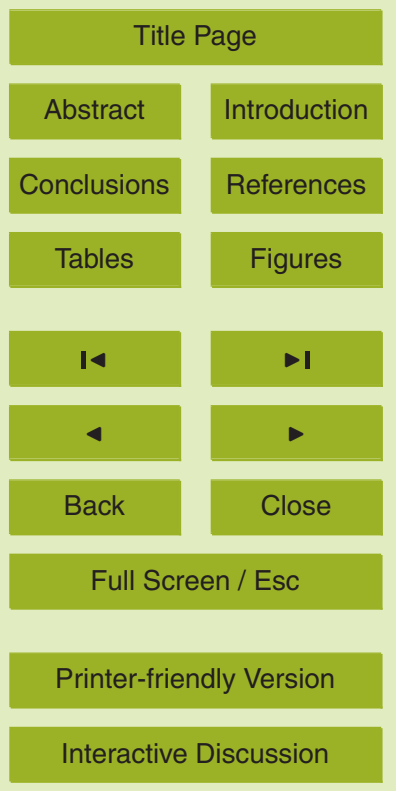


cross-variograms between $R_{\mathrm{s}}$ and $R_{\mathrm{a}}$ and $R_{\mathrm{h}}$, respectively, on 5 May are shown in Fig. 6b. $R_{\mathrm{s}}$ showed a strong spatial dependence on $R_{\mathrm{a}}$ up to a range of $12.3 \mathrm{~m}$, while no spatial dependence of $R_{\mathrm{s}}$ on $R_{\mathrm{h}}$ was observed.

Due to the setup-based distance between the soil collars of $R_{\mathrm{s}}$ and $R_{\mathrm{a}}$ and the de5 tected stochastic spatial variability of $R_{\mathrm{h}}$, it was to be expected that the indirect determination of $R_{\mathrm{a}}$ (Eq. 1) adds small-scale variability to the spatial pattern of $R_{\mathrm{a}}$. Thus, the variograms for $R_{\mathrm{a}}$ represent a conservative estimate of its actual spatial dependence. The fact that computed $R_{\mathrm{a}}$ values exhibited stronger spatial dependence than both, $R_{\mathrm{S}}$ and $R_{\mathrm{h}}$, underlines the dominating role of plant roots in determining soil respiration 10 patterns and is reflected in the high spatial dependence of the spatial pattern of $R_{\mathrm{S}}$ from $R_{\mathrm{a}}$.

\section{Conclusions}

From the observations of the spatially averaged fluxes in time we conclude that the seasonal changes of total $R_{\mathrm{s}}$ in winter wheat result from a temporally more variable autotrophic component compared to a rather time-stable heterotrophic component. Soil temperature and water content seasonal changes explained $74 \%$ and $80 \%$ of the temporal variability in total and autotrophic soil respiration, respectively.

We detected high spatial variations in the autotrophic component, attributed to the heterogeneity in local root development, which then mainly caused the variability of total soil respiration in space. During the final period of plant growth, when the root system is almost fully developed, autotrophic spatial variations are at maximum.

Total soil respiration and the autotrophic component showed moderate to strong spatial dependence in contrast to a predominantly random distribution of $R_{\mathrm{h}}$ in space. From high correlation between the spatial patterns of total soil respiration and the autotrophic component we conclude, that the pattern of total soil respiration basically resembles the autotrophic pattern. The lack of spatial autocorrelation in the heterotrophic component pattern is mostly responsible for the stochastic variations in the total soil respiration pattern.
BGD

7, 9137-9173, 2010

\section{Spatial and seasonal variability of soil respiration}

N. Prolingheuer et al.

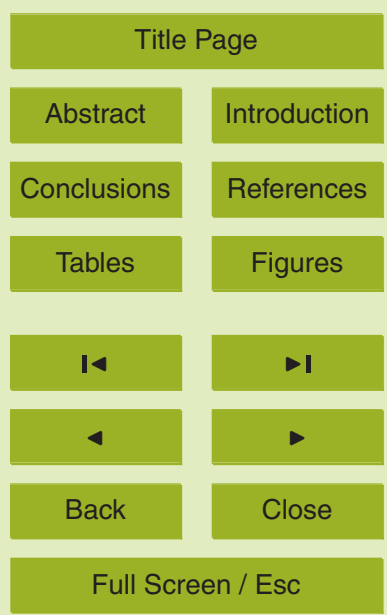

Printer-friendly Version

Interactive Discussion 
In conclusion, the observations prove that the spatial and seasonal variability of soil respiration in winter wheat basically originates from the variability of the autotrophic component.

All this indicates that chamber-based measurements of total soil respiration in 5 cropped systems require an adequate spatial sampling design accounting for the spatial autocorrelation resulting from the autotrophic component. Further, for those periods when spatial variability of autotrophic and consequently total soil respiration is at maximum, sampling at a high spatial density is required in order to ensure representative average fluxes. However, concerning the spatial variability this may in part be a specific 10 result for winter wheat. Other crops planted in rows would add another component to the spatial variation of fluxes.

Acknowledgements. We thank Carmen Schumann, Christian Steenpass and Rainer Harms for their support in the experimental setup and in taking soil respiration, water content and soil temperature measurements. We also thank Ferdinand Engels for constructing the TDR probes and Alexander Schlote. We gratefully acknowledge financial support by the SFB/TR 32 "Patterns in Soil-Vegetation-Atmosphere Systems: Monitoring, Modelling, and Data Assimilation" funded by the Deutsche Forschungsgemeinschaft (DFG) and by TERENO Terrestrial Environmental Observatories funded by the Federal Ministry of Education and Research (BMBF). A. Graf would 20 like to thank the DFG for funding his contribution to the study within the framework of the project GR2687/3-1: "Links between local scale and catchment scale measurements and modelling of gas exchange processes over land surfaces".

\section{References}

Akaike, $\mathrm{H}$.: Information theory and an extension of the maximum likelihood principle, in: Proc. 25 of the 2nd Int. Symp. on Information Theory, edited by: Petrov, B. N. and Csaki, F., Akademai Kiado, Budapest, 267-281, 1973. 9143

Akaike, H.: New look at statistical-model identification, IEEE T. Automat. Contr., AC19, 716723, 1974. 9143

\section{BGD}

7, 9137-9173, 2010

\section{Spatial and seasonal variability of soil respiration}

N. Prolingheuer et al.

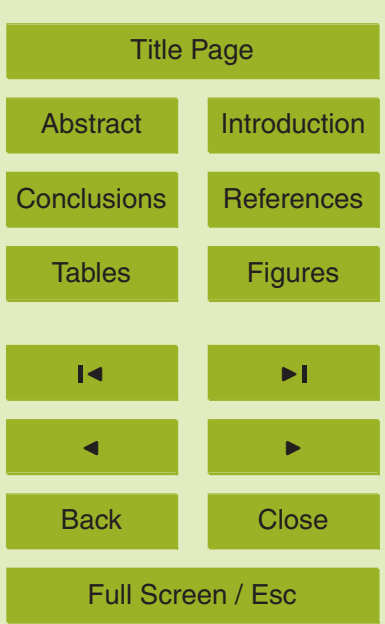

Printer-friendly Version

Interactive Discussion 
Almagro, M., Lopez, J., Querejeta, J. I., and Martinez-Mena, M.: Temperature dependence of soil $\mathrm{CO}_{2}$ efflux is strongly modulated by seasonal patterns of moisture availability in a Mediterranean ecosystem, Soil Biol. Biochem., 41, 594-605, doi:10.1016/j.soilbio. 2008.12.021, 2009. 9140, 9150

5 Andersen, C., Nikolov, I., Nikolova, P., Matyssek, R., and Haberle, K.: Estimating "autotrophic" belowground respiration in spruce and beech forests: decreases following girdling, Eur. J. Forest Res., 124, 155-163, doi:10.1007/s10342-005-0072-8, 2005. 9139

Aubinet, M., Moureaux, C., Bodson, B., Dufranne, D., Heinesch, B., Suleau, M., Vancutsem, F., and Vilret, A.: Carbon sequestration by a crop over a 4-year sugar beet/winter wheat/seed potato/winter wheat rotation cycle, Agr. Forest Meteorol., 149, 407-418, doi:10.1016/j.agrformet.2008.09.003, 2009. 9139, 9140

Baggs, E. M.: Partitioning the components of soil respiration: a research challenge, Plant Soil, 284, 1-5, 2006. 9139, 9142

Bahn, M., Rodeghiero, M., Anderson-Dunn, M., Dore, S., Gimeno, C., Droesler, M., 15 Williams, M., Ammann, C., Berninger, F., Flechard, C., Jones, S., Balzarolo, M., Kumar, S., Newesely, C., Priwitzer, T., Raschi, A., Siegwolf, R., Susiluoto, S., Tenhunen, J., Wohlfahrt, G., and Cernusca, A.: Soil respiration in European grasslands in relation to climate and assimilate supply, Ecosystems, 11, 1352-1367, doi:10.1007/s10021-008-9198-0, 2008. 9140

20 Beyer, L.: Intersite characterization and variability of soil respiration in different arable and forest soils, Biol. Fert. Soils, 12, 122-126, 1991. 9148

Bond-Lamberty, B., Wang, C. K., and Gower, S. T.: A global relationship between the heterotrophic and autotrophic components of soil respiration?, Glob. Change Biol., 10, 17561766, doi:10.1111/j.1365-2486.2004.00816.x, 2004. 9139

Borken, W., Davidson, E. A., Savage, K., Gaudinski, J., and Trumbore, S. E.: Drying and wetting effects on carbon dioxide release from organic horizons, Soil Sci. Soc. Am. J., 67, 1888-1896, 2003. 9140, 9150

Bowden, R. D., Nadelhoffer, K. J., Boone, R. D., Melillo, J. M., and Garrison, J. B.: Contributions of aboveground litter, belowground litter, and root respiration to total soil respiration in 30 a temperature mixed hardwood forest, Can. J. Forest Res., 23, 1402-1407, 1993. 9142

Buchmann, N.: Biotic and abiotic factors controlling soil respiration rates in Picea abies stands, Soil Biol. Biochem., 32, 1625-1635, 2000. 9140, 9149

Cambardella, C. A., Moorman, T. B., Novak, J. M., Parkin, T. B., Karlen, D. L., Turco, R. F., and

BGD

$7,9137-9173,2010$

\section{Spatial and seasonal variability of soil respiration}

N. Prolingheuer et al.

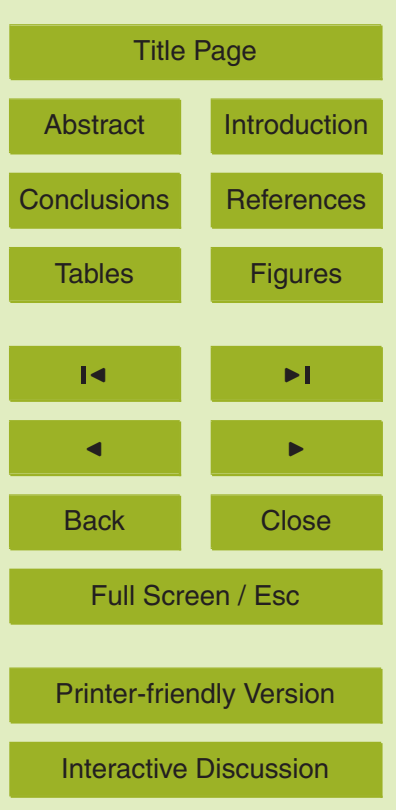


Konopka, A. E.: Field-scale variability of soil properties in Central lowa soils, Soil Sci. Soc. Am. J., 58, 1501-1511, 1994. 9146, 9154

Chang, S.-C., Tseng, K.-H., Hsia, Y.-J., Wang, C.-P., and Wu, J.-T.: Soil respiration in a subtropical montane cloud forest in Taiwan, Agr. Forest Meteorol., 148, 788-798, 5 doi:10.1016/j.agrformet.2008.01.003, 2008. 9140

Chen, D. C., Lu, C. T., Kou, Y. F., and Chen, F.: On detecting spatial outliers, Geoinformatica, 12, 455-475, 2008. 9144

Cressie, N. and Hawkins, D. M.: Robust estimation of the variogram .1., J. Int. Ass. Math. Geol., 12, 115-125, 1980. 9144, 9145

10 Davidson, E. A. and Janssens, I. A.: Temperature sensitivity of soil carbon decomposition and feedbacks to climate change, Nature, 440, 165-173, doi:10.1038/nature04514, 2006. 9139, 9149

Davidson, E. A., Belk, E., and Boone, R. D.: Soil water content and temperature as independent or confounded factors controlling soil respiration in a temperate mixed hardwood forest, Glob. Change Biol., 4, 217-227, 1998. 9139, 9140, 9149, 9150

Davidson, E. A., Verchot, L. V., Cattanio, J. H., Ackerman, I. L., and Carvalho, J. E. M.: Effects of soil water content on soil respiration in forests and cattle pastures of eastern Amazonia, Biogeochemistry, 48, 53-69, 2000. 9139

Deutsch, C. and Journel, A.: GSLIB: Geostatistical Software Library and User's Guide, 2nd edn., Oxford Press, New York, 1998. 9147

Diggle, P. J. and Ribeiro, P. J.: Model-Based Geostatistics, 1st edn., Springer Series in Statistics, Springer, New York, http://www.worldcat.org/isbn/0387329072, 2007. 9144

Eaton, J. W.: GNU Octave Manual, Network Theory Limited, Bristol, 2002. 9146

Epron, D., Farque, L., Lucot, E., and Badot, P. M.: Soil $\mathrm{CO}_{2}$ efflux in a beech forest: dependence on soil temperature and soil water content, Ann. Forest Sci., 56, 221-226, 1999. 9148

Fang, C. and Moncrieff, J. B.: The dependence of soil $\mathrm{CO}_{2}$ efflux on temperature, Soil Biol. Biochem., 33, 155-165, 2001. 9139, 9140, 9149

Fang, C., Moncrieff, J. B., Gholz, H. L., and Clark, K. L.: Soil $\mathrm{CO}_{2}$ efflux and its spatial variation in a Florida slash pine plantation, Plant Soil, 205, 135-146, 1998. 9140

30 FAO: World Reference Base for Soil Resources, 2006: A Framework for International Classification, Correlation and Communication, Food and Agriculture Organization of the United Nations, Rome, 2006. 9141

Gaudinski, J. B., Trumbore, S. E., Davidson, E. A., and Zheng, S. H.: Soil carbon cycling in

BGD

7, 9137-9173, 2010

\section{Spatial and seasonal variability of soil respiration}

N. Prolingheuer et al.



Printer-friendly Version

Interactive Discussion 
a temperate forest: radiocarbon-based estimates of residence times, sequestration rates and partitioning of fluxes, Biogeochemistry, 51, 33-69, 2000. 9139

Goovaerts, P.: Geostatistical tools for characterizing the spatial variability of microbiological and physico-chemical soil properties, Biol. Fert. Soils, 27, 315-334, 1998. 9144, 9154

5 Goovaerts, P.: Geostatistics in soil science: state-of-the-art and perspectives, Geoderma, 89, 1-45, 1999. 9144, 9147

Goovaerts, P.: Estimation or simulation of soil properties? An optimization problem with conflicting criteria, Geoderma, 97, 165-186, 2000. 9147

Goovaerts, P.: Geostatistical modelling of uncertainty in soil science, Geoderma, 103, 3-26, 2001. 9147

Han, G. X., Zhou, G. S., Xu, Z. Z., Yang, Y., Liu, J. L., and Shi, K. Q.: Biotic and abiotic factors controlling the spatial and temporal variation of soil respiration in an agricultural ecosystem, Soil Biol. Biochem., 39, 418-425, 2007. 9140, 9152

Hanson, P. J., Edwards, N. T., Garten, C. T., and Andrews, J. A.: Separating root and soil micro15 bial contributions to soil respiration: a review of methods and observations, Biogeochemistry, 48, 115-146, 2000. 9139, 9142

Herbst, M., Prolingheuer, N., Graf, A., Huisman, J., Weihermüller, L., and Vanderborght, J.: Characterisation and understanding of bare soil respiration spatial variability at plot scale, Vadose Zone J., 8(3), 762-771, 2009. 9150, 9153, 9154

20 Hibbard, K. A., Law, B. E., Reichstein, M., and Sulzman, J.: An analysis of soil respiration across Northern Hemisphere temperate ecosystems, Biogeochemistry, 73, 29-70, 2005. 9151

Hirobe, M., Ohte, N., Karasawa, N., Zhang, G. S., Wang, L. H., and Yoshikawa, K.: Plant species effect on the spatial patterns of soil properties in the Mu-us desert ecosystem, Inner Mongolia, China, Plant Soil, 234, 195-205, 2001. 9146

Hurvich, C. M. and Tsai, C. L.: Regression and time-series model selection in small samples, Biometrika, 76, 297-307, 1989. 9144

IPCC: Fourth Assessment Report: Climate Change 2007: The AR4 Synthesis Report, Intergovernmental Panel on Climate Change, Geneva, http://www.ipcc.ch/ipccreports/ar4-wg1.htm, $30 \quad$ 2007. 9138

Journel, A. G. and Huijbregts, C. J.: Mining Geostatistics, Academic Press, London New York, 1978. 9144

Katsalirou, E., Deng, S. P., Nofziger, D. L., Gerakis, A., and Fuhlendorf, S. D.: Spatial structure

BGD

7, 9137-9173, 2010

\section{Spatial and seasonal variability of soil respiration}

N. Prolingheuer et al.




of microbial biomass and activity in prairie soil ecosystems, Eur. J. Soil Biol., 46, 181-189, doi:10.1016/j.ejsobi.2010.04.005, 2010. 9153

Kätterer, T., Hansson, A.-C., and Andrén, O.: Wheat root biomass and nitrogen dynamics effects of daily irrigation and fertilization, Plant Soil, 151, 21-30, doi:10.1007/BF00010782, 1993. 9142

King, S. L.: Sequential Gaussian simulation vs. simulated annealing for locating pockets of high-value commercial trees in Pennsylvania, Ann. Oper. Res., 95, 177-203, 2000. 9147

Kou, Y., Lu, C.-T., and Chen, D.: Spatial weighted outlier detection, in: 2006 SIAM Conference on Data Mining, Bethesda, Maryland, edited by: Ghosh, J., Lambert, D., Skillicorn, D. B., 10 and Scrivastava, J., SIAM, Philadelphia, 2006. 9144

Kuzyakov, Y.: Sources of $\mathrm{CO}_{2}$ efflux from soil and review of partitioning methods, Soil Biol. Biochem., 38, 425-448, 2006. 9139

Lloyd, J. and Taylor, J. A.: On the temperature-dependence of soil respiration, Funct. Ecol., 8, 315-323, 1994. 9139, 9140, 9142, 9149

15 Mahecha, M. D., Reichstein, M., Carvalhais, N., Lasslop, G., Lange, H., Seneviratne, S. I., Vargas, R., Ammann, C., Arain, M. A., Cescatti, A., Janssens, I. A., Migliavacca, M., Montagnani, L., and Richardson, A. D.: Global convergence in the temperature sensitivity of respiration at ecosystem level, Science, 329, 838-840, doi:10.1126/science.1189587, 2010. 9150

20 Martin, J. G. and Bolstad, P. V.: Annual soil respiration in broadleaf forests of Northern Wisconsin: influence of moisture and site biological, chemical, and physical characteristics, Biogeochemistry, 73, 149-182, 2005. 9150

Matheron, G.: Principles of geostatistics, Econ. Geol., 58, 1246-1266, doi:10.2113/ gsecongeo.58.8.1246, 1963. 9145

Mori, A. and Takeda, H.: Light-related competitive effects of overstory trees on the understory conifer saplings in a subalpine forest, J. Forest Res.-Jpn., 8, 163-168, 2003. 9146

Morris, S. J.: Spatial distribution of fungal and bacterial biomass in Southern Ohio hardwood forest soils: fine scale variability and microscale patterns, Soil Biol. Biochem., 31, 13751386, 1999. 9146, 9154

so Moureaux, C., Debacq, A., Hoyaux, J., Suleau, M., Tourneur, D., Vancutsem, F., Bodson, B., and Aubinet, M.: Carbon balance assessment of a Belgian winter wheat crop (Triticum aestivum L.), Glob. Change Biol., 14, 1353-1366, 2008. 9148

Moyano, F. E., Kutsch, W. L., and Schulze, E. D.: Response of mycorrhizal, rhizosphere and

\section{BGD}

7, 9137-9173, 2010

\section{Spatial and seasonal variability of soil respiration}

N. Prolingheuer et al.

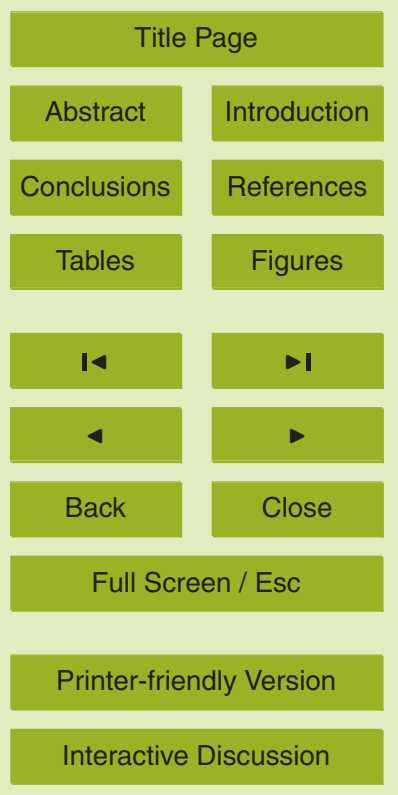


soil basal respiration to temperature and photosynthesis in a barley field, Soil Biol. Biochem., 39, 843-853, 2007. 9139, 9142, 9150

Nunan, N., Wu, K., Young, I., Crawford, J., and Ritz, K.: In situ spatial patterns of soil bacterial populations, mapped at multiple scales, in an arable soil, Microb. Ecol., 44, 296-305, 2002.

\section{3}

Pebesma, E.: Multivariable geostatistics in S: the gstat package, Comput Geosci-UK, 30, 683691, doi:10.1016/j.cageo.2004.03.012, 2004. 9146, 9147

$\mathrm{Qi}, \mathrm{Y}$. and $\mathrm{Xu}, \mathrm{M}$.: Separating the effects of moisture and temperature on soil $\mathrm{CO}_{2}$ efflux in a coniferous forest in the Sierra Nevada mountains, Plant Soil, 237, 15-23, 2001. 9140, 9143

R Development Core Team: R: a Language and Environment for Statistical Computing, R Foundation for Statistical Computing, Vienna, Austria, http://www.R-project.org, ISBN 3-90005107-0, 2005. 9146

Raich, J. W. and Schlesinger, W. H.: The global carbon-dioxide flux in soil respiration and its 15 relationship to vegetation and climate, Tellus, 44B, 81-99, 1992. 9139

Reichstein, M., Tenhunen, J. D., Roupsard, O., Ourcival, J. M., Rambal, S., Dore, S., and Valentini, R.: Ecosystem respiration in two Mediterranean evergreen Holm Oak forests: drought effects and decomposition dynamics, Funct. Ecol., 16, 27-39, 2002. 9140, 9149

Reichstein, M., Rey, A., Freibauer, A., Tenhunen, J., Valentini, R., Banza, J., Casals, P., Cheng, Y. F., Grunzweig, J. M., Irvine, J., Joffre, R., Law, B. E., Loustau, D., Miglietta, F., Oechel, W., Ourcival, J. M., Pereira, J. S., Peressotti, A., Ponti, F., Qi, Y., Rambal, S., Rayment, M., Romanya, J., Rossi, F., Tedeschi, V., Tirone, G., Xu, M., and Yakir, D.: Modeling temporal and large-scale spatial variability of soil respiration from soil water availability, temperature and vegetation productivity indices, Global Biogeochem. Cy., 17, 2003. 9143, 9151

Reichstein, M., Subke, J. A., Angeli, A. C., and Tenhunen, J. D.: Does the temperature sensitivity of decomposition of soil organic matter depend upon water content, soil horizon, or incubation time?, Glob. Change Biol., 11, 1754-1767, doi:10.1111/j.1365-2486.2005.001010.x, 2005. 9149

Rey, A., Pegoraro, E., Tedeschi, V., De Parri, I., Jarvis, P., and Valentini, R.: Annual variation in soil respiration and its components in a coppice oak forest in Central Italy, Glob. Change Biol., 8, 851-866, 2002. 9148

Robertson, G. P. and Freckman, D. W.: The spatial-distribution of nematode trophic groups across a cultivated ecosystem, Ecology, 76, 1425-1432, 1995. 9146

\section{BGD}

$7,9137-9173,2010$

\section{Spatial and seasonal variability of soil respiration}

N. Prolingheuer et al.

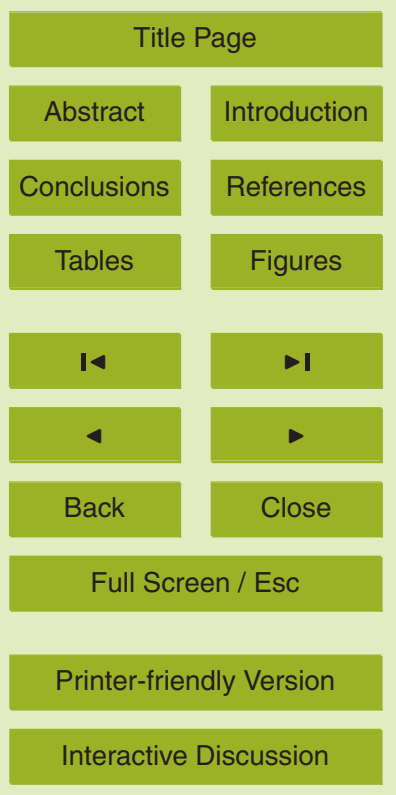


Rochette, P., Desjardins, R. L., and Pattey, E.: Spatial and temporal variability of soil respiration in agricultural fields, Can. J. Soil Sci., 71, 189-196, 1991. 9140, 9148, 9153, 9154, 9155

Rossi, R. E., Borth, P. W., and Tollefson, J. J.: Stochastic simulation for characterizing ecological spatial patterns and appraising risk, Ecol. Appl., 3, 719-735, 1993. 9147

5 Saiz, G., Green, C., Butterbach-Bahl, K., Kiese, R., Avitabile, V., and Farrell, E. P.: Seasonal and spatial variability of soil respiration in four Sitka spruce stands, Plant Soil, 287, 161-176, 2006. 9148

Sapronov, D. V. and Kuzyakov, Y. V.: Separation of root and microbial respiration: Comparison of three methods, Eurasian Soil Sci.+, 40, 775-784, 2007. 9139

10 Savage, K., Davidson, E. A., Richardson, A. D., and Hollinger, D. Y.: Three scales of temporal resolution from automated soil respiration measurements, Agr. Forest Meteorol., 149, 20122021, doi:10.1016/j.agrformet.2009.07.008, 2009. 9149

Savage, K. E. and Davidson, E. A.: A comparison of manual and automated systems for soil $\mathrm{CO}_{2}$ flux measurements: trade-offs between spatial and temporal resolution, J. Exp. Bot.,

15 54, 891-899, 2003. 9150

Shi, P. L., Zhang, X. Z., Zhong, Z. M., and Ouyang, H.: Diurnal and seasonal variability of soil $\mathrm{CO}_{2}$ efflux in a cropland ecosystem on the Tibetan Plateau, Agr. Forest Meteorol., 137, 220-233, 2006. 9143, 9149, 9151

Smith, P., Fang, C. M., Dawson, J. J. C., and Moncrieff, J. B.: Impact of global warming on soil organic carbon, Adv. Agron., 97, 1-43, doi:10.1016/S0065-2113(07)00001-6, 2008. 9138

Sotta, E., Meir, P., Malhi, Y., Nobre, A., Hodnett, M., and Grace, J.: Soil $\mathrm{CO}_{2}$ efflux in a tropical forest in the central Amazon, Glob. Change Biol., 10, 601-617, doi:10.1111/j.15298817.2003.00761.x, 2004. 9140

Storn, R. and Price, K.: Differential evolution - a simple and efficient heuristic for global optimization over continuous spaces, J. Global Optim., 11, 341-359, 1997. 9143, 9146

Stoyan, H., De-Polli, H., Bohm, S., Robertson, G. P., and Paul, E. A.: Spatial heterogeneity of soil respiration and related properties at the plant scale, Plant Soil, 222, 203-214, 2000. 9152, 9154

Subke, J. A., Reichstein, M., and Tenhunen, J. D.: Explaining temporal variation in soil $\mathrm{CO}_{2}$ efflux in a mature spruce forest in Southern Germany, Soil Biol. Biochem., 35, 1467-1483, 2003. 9149

Subke, J. A., Inglima, I., and Cotrufo, M. F.: Trends and methodological impacts in soil $\mathrm{CO}_{2}$ efflux partitioning: a metaanalytical review, Glob. Change Biol., 12, 921-943, 2006. 9142

BGD

7, 9137-9173, 2010

\section{Spatial and seasonal variability of soil respiration}

N. Prolingheuer et al.



Printer-friendly Version

Interactive Discussion 
Tang, J. W. and Baldocchi, D. D.: Spatial-temporal variation in soil respiration in an oak-grass savanna ecosystem in California and its partitioning into autotrophic and heterotrophic components, Biogeochemistry, 73, 183-207, 2005. 9139, 9140

Tang, J. W., Misson, L., Gershenson, A., Cheng, W. X., and Goldstein, A. H.: Continuous 5 measurements of soil respiration with and without roots in a ponderosa pine plantation in the Sierra Nevada Mountains, Agr. Forest Meteorol., 132, 212-227, 2005. 9142

Tang, X. L., Zhou, G. Y., Liu, S. G., Zhang, D. Q., Liu, S. Z., Li, J., and Zhou, C. Y.: Dependence of soil respiration on soil temperature and soil moisture in successional forests in southern China, J. Integr. Plant Biol., 48, 654-663, 2006. 9140, 9143, 9151

10 Topp, G., Davis, J., and Annan, A.: Electromagnetic determination of soil-water content - measurements in coaxial transmission-lines, Water Resour. Res, 16, 574-582, 1980. 9142

Wang, W. and Fang, J.: Soil respiration and human effects on global grasslands, Fall Annual Meeting of the American-Geophysical-Union, San Francisco, CA, 2005, Global Planet. Change, 67, 20-28, doi:10.1016/j.gloplacha.2008.12.011, 2009. 9139

15 Webster, R.: Regression and functional relations, Eur. J. Soil Sci., 48, 557-566, 1997. 9150

Weihermüller, L., Huisman, J. A., Lambot, S., Herbst, M., and Vereecken, H.: Mapping the spatial variation of soil water content at the field scale with different ground penetrating radar techniques, J. Hydrol., 340, 205-216, 2007. 9141

Western, A. W. and Blöschl, G.: On the spatial scaling of soil moisture, J. Hydrol., 217, 203224, 1999. 9154

Wilhelm, W., Mielke, L., and Fenster, C.: Root Development of Winter-Wheat as Related to Tillage Practice in Western Nebraska, Agron. J., 74, 85-88, 1982. 9142

Zimmermann, M., Meir, P., Bird, M. I., Malhi, Y., and Ccahuana, A. J. Q.: Climate dependence of heterotrophic soil respiration from a soil-translocation experiment along a $3000 \mathrm{~m}$ 2389.2009.01175.x, 2009. 9140

\section{BGD}

7, 9137-9173, 2010

\section{Spatial and seasonal variability of soil respiration}

N. Prolingheuer et al.

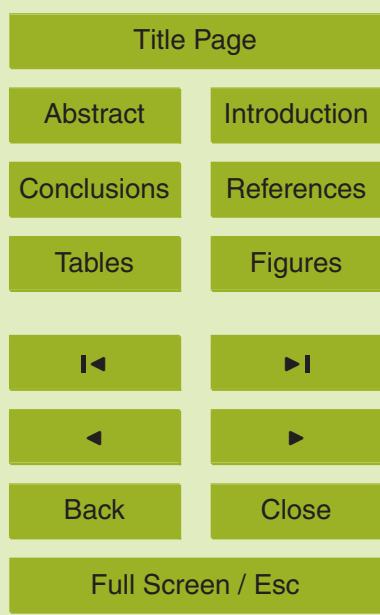

Printer-friendly Version

Interactive Discussion 
BGD

7, 9137-9173, 2010

\section{Spatial and seasonal variability of soil respiration}

Table 1. Correlation matrix of soil respiration, soil temperature, water content and leaf area index.

\begin{tabular}{|c|c|c|c|c|c|c|c|c|c|}
\hline & $R_{\mathrm{s}}$ & $R_{\mathrm{h}}$ & $R_{\mathrm{a}}$ & $T_{\mathrm{h}}$ & $T_{\mathrm{s}}$ & $\theta_{\mathrm{h}}$ & $\theta_{\mathrm{s}}$ & $\mathrm{LAI}_{\mathrm{g}}$ & $L A I_{b}$ \\
\hline$R_{\mathrm{s}}$ & & 0.45 & $0.91^{* * *}$ & $-0.61^{*}$ & -0.10 & 0.41 & $0.51^{*}$ & $0.62^{* *}$ & 0.38 \\
\hline$R_{\mathrm{h}}$ & 0.45 & & 0.04 & -0.02 & 0.10 & $0.53^{*}$ & 0.32 & 0.38 & -0.04 \\
\hline$R_{\mathrm{a}}$ & $0.91^{* * *}$ & 0.04 & & $-0.70^{* *}$ & $-0.72^{* * *}$ & 0.22 & $0.8^{* * *}$ & 0.46 & $-0.79^{* * *}$ \\
\hline$T_{h}$ & $-0.61^{*}$ & -0.02 & $-0.70^{* *}$ & & $1.00^{* * *}$ & -0.25 & -0.55 & $-0.89^{* * *}$ & $0.77^{* * *}$ \\
\hline$T_{\mathrm{s}}^{\prime \prime}$ & -0.10 & 0.10 & $-0.72^{* * *}$ & $1.00^{* * *}$ & & -0.17 & $-0.69^{* *}$ & -0.37 & $0.82^{* * *}$ \\
\hline$\theta_{h}$ & 0.41 & $0.53^{*}$ & 0.22 & -0.25 & -0.17 & & $0.52^{*}$ & 0.38 & -0.02 \\
\hline$\theta_{\mathrm{s}}$ & $0.51^{*}$ & 0.32 & $0.80^{*}$ & -0.55 & $-0.69^{* *}$ & $0.52^{*}$ & & 0.29 & $-0.83^{* * *}$ \\
\hline $\mathrm{LAl}_{\mathrm{a}}$ & $0.62^{* *}$ & 0.38 & 0.46 & $-0.89^{* * *}$ & -0.37 & 0.38 & 0.29 & & -0.31 \\
\hline $\mathrm{LAI}_{\mathrm{b}}^{\mathrm{g}}$ & -0.38 & -0.04 & $-0.79^{* * *}$ & $0.77^{* * *}$ & $0.82^{* * *}$ & -0.02 & $-0.83^{* * *}$ & -0.31 & \\
\hline
\end{tabular}

$R_{\mathrm{s}}$ : total soil respiration, $R_{\mathrm{h}}$ : heterotrophic soil respiration, $R_{\mathrm{a}}$ : autotrophic soil respiration, $T_{\mathrm{h}}$ : soil temperature in $6 \mathrm{~cm}$ depth at locations of heterotrophic soil respiration, $T_{\mathrm{s}}$ : soil temperature in $6 \mathrm{~cm}$ depth at locations of total soil respiration, $\theta_{\mathrm{h}}$ : water content at $6 \mathrm{~cm}$ depth at locations of heterotrophic soil respiration, $\theta_{\mathrm{s}}$ : water content at $6 \mathrm{~cm}$ depth at locations of total soil respiration, $\mathrm{LAl}_{\mathrm{g}}$ : green leaf area index, $\mathrm{LAl}_{\mathrm{b}}$ : brown leaf area index, $\mathrm{RMSE}$ : root mean square error, $r$ : coefficient of correlation, ${ }^{*} p<0.05,{ }^{* *} p<0.01,{ }^{* * *} p<0.001$.
N. Prolingheuer et al.

\section{Title Page}

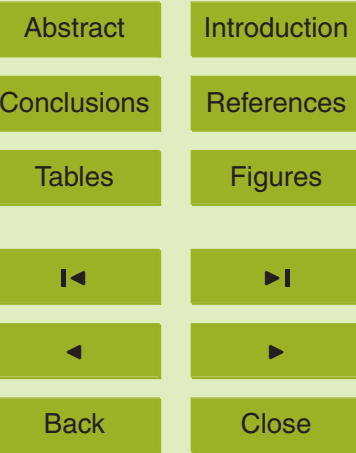

Full Screen / Esc

Printer-friendly Version

Interactive Discussion 
Table 2. Regression parameters and statistics for the seasonal relationship between soil respiration, soil temperature, water content and leaf area index.

\begin{tabular}{|c|c|c|c|c|c|c|c|c|c|}
\hline Variables & Eq. & $a$ & $b$ & $c$ & $d$ & RMSE & $r^{2}$ & $\mathrm{AIC}_{\mathrm{c}}$ & $p$ \\
\hline$R_{\mathrm{h}}=f\left(T_{\mathrm{h}}\right)$ & (2) & 2.11 & 0 & - & - & 1.34 & 0.00 & -26.9 & \\
\hline$R_{\mathrm{h}}=f\left(\theta_{\mathrm{h}}\right)$ & (3) & 8.01 & - & 0.957 & - & 1.32 & 0.27 & -34.3 & ${ }^{*}$ \\
\hline$R_{\mathrm{h}}=f\left(T_{\mathrm{h}}, \theta_{\mathrm{h}}\right)$ & (5) & 7.56 & 0.005 & 0.968 & - & 1.15 & 0.27 & -28.4 & ${ }^{* *}$ \\
\hline$R_{\mathrm{a}}=f\left(T_{\mathrm{s}}\right)$ & (2) & 1.77 & -0.048 & - & - & 3.04 & 0.55 & -2.5 & ${ }^{* * *}$ \\
\hline$R_{\mathrm{a}}=f\left(\theta_{\mathrm{s}}\right)$ & (3) & 84.33 & - & 3.159 & - & 1.82 & 0.68 & -20.0 & ${ }^{* * *}$ \\
\hline$R_{\mathrm{a}}=f\left(\mathrm{LAI}_{\mathrm{g}}\right)$ & (4) & 0.37 & - & - & 0.173 & 3.00 & 0.21 & -4.8 & \\
\hline$R_{\mathrm{a}}=f\left(T_{\mathrm{s}}, \theta_{\mathrm{s}}\right)$ & (5) & 164.74 & -0.007 & 2.915 & - & 1.43 & 0.80 & -21.2 & *** \\
\hline$R_{\mathrm{a}}=f\left(T_{\mathrm{s}}, \theta_{\mathrm{s}}, \mathrm{LAl}_{\mathrm{g}}\right)$ & $(6)$ & 128.19 & -0.009 & 2.478 & -0.003 & 1.42 & 0.81 & -17.1 & ${ }^{* * *}$ \\
\hline$R_{\mathrm{s}}=f\left(T_{\mathrm{s}}\right)$ & $(2)$ & 3.14 & -0.008 & - & - & 4.17 & 0.01 & 5.9 & \\
\hline$R_{\mathrm{s}}=f\left(\theta_{\mathrm{s}}\right)$ & (3) & 15.98 & - & 1.138 & - & 1.94 & 0.72 & -17.8 & ${ }^{* * *}$ \\
\hline$R_{\mathrm{s}}=f\left(\mathrm{LAl}_{\mathrm{g}}\right)$ & (4) & 2.02 & - & - & 0.282 & 3.37 & 0.38 & -3.8 & ${ }^{* *}$ \\
\hline$R_{\mathrm{s}}=f\left(T_{\mathrm{s}}, \hat{\theta}_{\mathrm{s}}\right)$ & (5) & 18.02 & -0.012 & 1.102 & - & 1.85 & 0.74 & -13.1 & ${ }^{* * *}$ \\
\hline$R_{\mathrm{s}}=f\left(T_{\mathrm{s}}, \theta_{\mathrm{s}}, \mathrm{LAI}_{\mathrm{g}}\right)$ & (6) & 15.35 & 0.026 & 1.470 & 0.140 & 1.72 & 0.77 & -10.9 & ${ }^{* * *}$ \\
\hline
\end{tabular}

\section{Spatial and seasonal variability of soil respiration}

N. Prolingheuer et al.

$R_{\mathrm{s}}$ : total soil respiration, $R_{\mathrm{h}}$ : heterotrophic soil respiration, $R_{\mathrm{a}}$ : autotrophic soil respiration, $T_{\mathrm{h}}$ : soil temperature in $6 \mathrm{~cm}$ depth at locations of heterotrophic respiration, $T_{\mathrm{s}}$ : soil temperature in $6 \mathrm{~cm}$ depth at locations of total soil respiration, $\theta_{\mathrm{h}}$ : water content at $6 \mathrm{~cm}$ depth at locations of heterotrophic respiration, $\theta_{\mathrm{s}}$ : water content at $6 \mathrm{~cm}$ depth at locations of total soil respiration, $\mathrm{LAl}_{\mathrm{g}}$ : green leaf area index, Eq.: model equation, $a-d$ : fitted parameters, RMSE: root mean square error, $r^{2}$ : coefficient of determination, $\mathrm{AIC}_{\mathrm{c}}$ : corrected Akaike Information Criterion, $p$ : $\mathrm{p}$-value: ${ }^{*} p<0.05,{ }^{* *} p<0.01$, ${ }^{* * *} p<0.001$

\section{Title Page}

\section{Abstract}

Introduction

Conclusions

References

Tables

Figures

14

4

Back

Close

\section{Full Screen / Esc}

Printer-friendly Version

Interactive Discussion 
BGD

7, 9137-9173, 2010

\section{Spatial and seasonal variability of soil respiration}

Table 3. Variogram parameters of soil respiration for selected sampling dates.

\begin{tabular}{|c|c|c|c|c|c|c|c|c|c|c|c|c|c|c|c|}
\hline \multirow[b]{2}{*}{ date } & \multicolumn{5}{|c|}{ Total soil respiration $\left(R_{\mathrm{s}}\right)$} & \multicolumn{5}{|c|}{ Heterotrophic soil respiration $\left(R_{\mathrm{h}}\right)$} & \multicolumn{5}{|c|}{ Autotrophic soil respiration $\left(R_{\mathrm{a}}\right)$} \\
\hline & $c_{0}$ & $c_{1}$ & $n_{\mathrm{c}}$ & $a_{1}$ & $r^{2}$ & $c_{0}$ & $c_{1}$ & $n_{\mathrm{c}}$ & $a_{1}$ & $r^{2}$ & $c_{0}$ & $c_{1}$ & $n_{\mathrm{c}}$ & $a_{1}$ & $r^{2}$ \\
\hline $16 \mathrm{Apr}$ & 0.009 & 0.012 & .43 & 7.6 & 0 & 010 & 0.000 & 1.00 & 0.0 & 0. & .025 & .018 & 0.59 & 4.4 & 0.55 \\
\hline $22 \mathrm{Apr}$ & 0.021 & 0.003 & 0.87 & 17.9 & 0.03 & & & 0.82 & 35.1 & 0.45 & 0.082 & & 0.88 & 23.6 & 0.57 \\
\hline $30 \mathrm{Apr}$ & 0.004 & 0.013 & 0.26 & 13.1 & 0.74 & .016 & 0.000 & 0.99 & 22.7 & 0.20 & 0.033 & 0.012 & 0.73 & 19.1 & 0.21 \\
\hline 5 May & 0.002 & 0.030 & 0.06 & 7.4 & 0.6 & & & 1.00 & 0.0 & 0.00 & & & 0. & 1 & 0.77 \\
\hline 13 May & 0.045 & 0.034 & 0.57 & 26.0 & 0.46 & 16 & 0. & 0.57 & 10.0 & 0.21 & 21 & & 0.16 & 23.6 & 0.73 \\
\hline 20 May & 0.009 & 0.027 & 0.26 & 19.0 & 0.93 & 0.007 & 0.014 & 0.34 & 8.7 & 0.81 & 0.006 & & 0.10 & 24.1 & 0.96 \\
\hline 27 May & 0.020 & 0.000 & 1.00 & 0.0 & 0.0 & 0.010 & 0. & 0.76 & 23.3 & 0. & & & 0.04 & 11.7 & 0.83 \\
\hline 28 May & 0.006 & & 0.35 & 10.5 & & & & 1.00 & & 0. & & & 0.00 & & 0.71 \\
\hline 3 Jun & 0.015 & 0.002 & 0.86 & 23.2 & 0.12 & 0.002 & 0.009 & 0.21 & 10.9 & 0.90 & 0.008 & 0.011 & 0.42 & 19.5 & 0.88 \\
\hline 17 Jun & 0.003 & 0.006 & 0.36 & 23.1 & 0.95 & 0.016 & 0.000 & 1.00 & 0.0 & 0.00 & 0.082 & 0.054 & 0.60 & 8.7 & 0.51 \\
\hline 24 Jun & 0.022 & 0.000 & 1.00 & 0.0 & 0.00 & 0.004 & 0.020 & 0.18 & 6.1 & 0.10 & 0.000 & 0.078 & 0.00 & 11.2 & 0.30 \\
\hline $1 \mathrm{Jul}$ & 0.005 & 0.003 & 0.63 & 14.6 & 0.14 & 0.015 & 0.000 & 1.00 & 0.0 & 0.00 & 0.003 & 0.109 & 0.03 & 4.7 & 0.00 \\
\hline $15 \mathrm{Jul}$ & 0.005 & 0.015 & 0.23 & 35.1 & 0.78 & 0.026 & 0.000 & 1.00 & 0.0 & 0.00 & 0.007 & 0.004 & 0.62 & 28.1 & 0.56 \\
\hline $22 \mathrm{Jul}$ & 0.019 & 0.000 & 1.00 & 0.0 & 0.00 & 0.000 & 0.015 & 0.03 & 13.4 & 0.84 & 0.004 & 0.006 & 0.44 & 11.8 & 0.84 \\
\hline
\end{tabular}

$c_{0}$ : nugget, $c_{1}$ : structural variance, $n_{\mathrm{c}}$ : nugget coefficient $\left(c_{0}\left(c_{0}+c_{1}\right)^{-1}\right), a_{1}$ : range of spatial autocorrelation, $r^{2}$ : coefficient of determination of fit. Values for $c_{0}$ and $c_{1}$ are given in $\log _{10}\left(\mu \mathrm{molm} \mathrm{m}^{-2} \mathrm{~s}^{-1}\right)^{2}$ and values given for $a_{1}$ are given in meters.
N. Prolingheuer et al.

\section{Title Page}



Full Screen / Esc

Printer-friendly Version

Interactive Discussion 


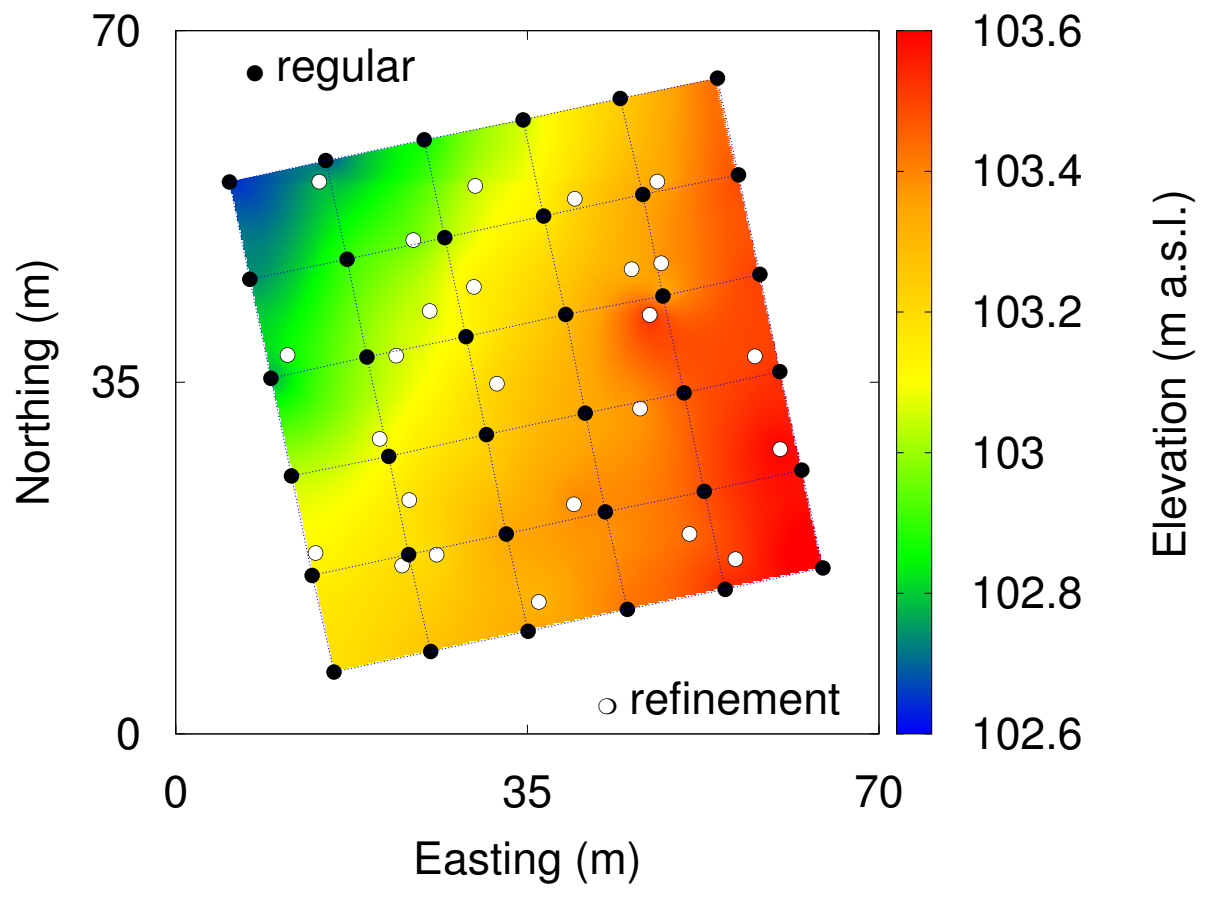

Fig. 1. Sampling grid at the $50 \times 50 \mathrm{~m}$ plot including sampling points on a regular grid with a mesh size of $10 \mathrm{~m}$ and randomly located sampling points for local refinement. Each sampling point represents a $50 \mathrm{~cm}$ and a $7 \mathrm{~cm}$ soil collar being closely located to each other.

\section{BGD}

7, 9137-9173, 2010

Spatial and seasonal variability of soil respiration

N. Prolingheuer et al.

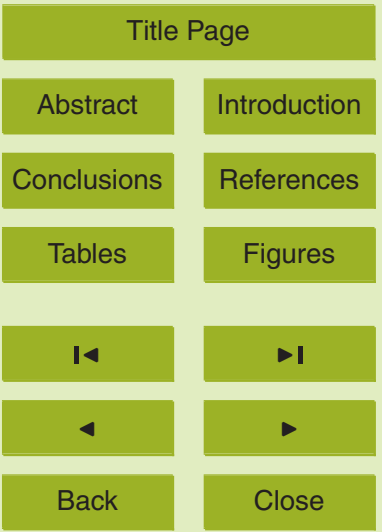

Full Screen / Esc

Printer-friendly Version

Interactive Discussion 


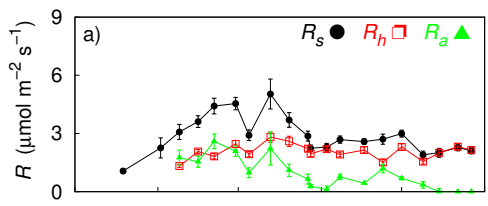

BGD

7, 9137-9173, 2010

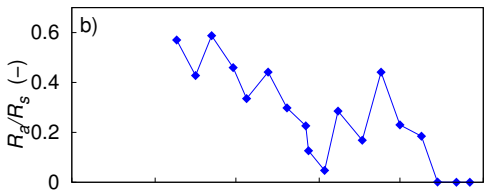

Spatial and seasonal variability of soil respiration

N. Prolingheuer et al.
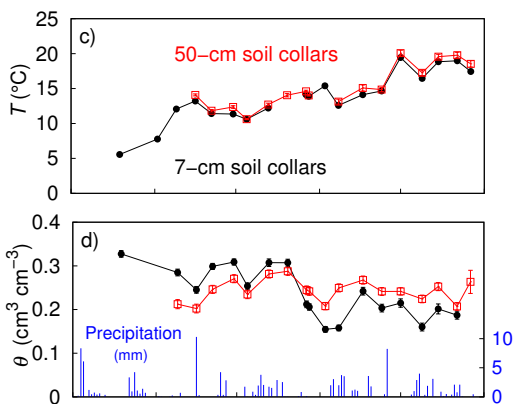

Title Page

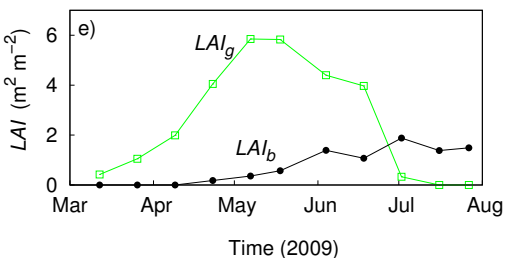

4

4

Back
Introduction

Abstract

References

Tables

Figures

\section{Full Screen / Esc}

Printer-friendly Version

Interactive Discussion (b) the contribution of $R_{\mathrm{a}}$ to $R_{\mathrm{s}}$, (c) soil temperature $(T)$ and (d) water content in $6 \mathrm{~cm}$ depth $(\theta)$ at locations of heterotrophic (red line) and total soil respiration (black line), and (e) green ( $\mathrm{LAI}_{\mathrm{g}}$ ) and brown $\left(\mathrm{LAl}_{\mathrm{b}}\right)$ leaf area index. Errorbars represent the 95\% confidence interval. 


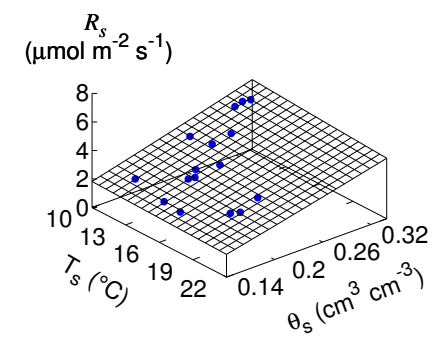

a)
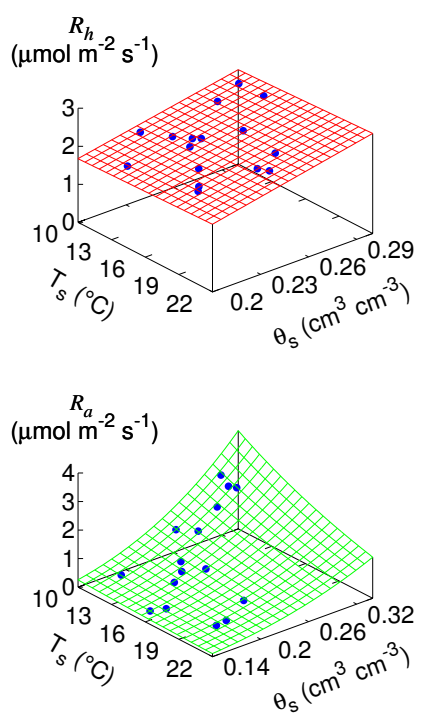

b)

c)

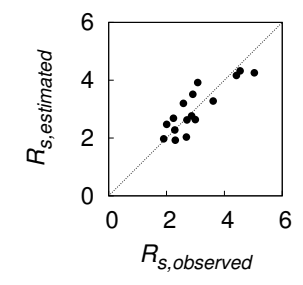

$$
\begin{aligned}
& r^{2}=0.74 \\
& \mathrm{RMSE}^{2}=1.85 \\
& \mathrm{AIC}_{\mathrm{c}}=-13.1 \\
& p<0.001
\end{aligned}
$$

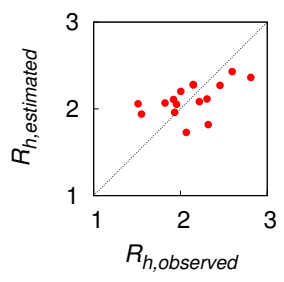

$$
\begin{aligned}
& r^{2}=0.27 \\
& \text {RMSE}^{2}=1.15 \\
& \text { AIC }_{c}=-28.4 \\
& p<0.05
\end{aligned}
$$

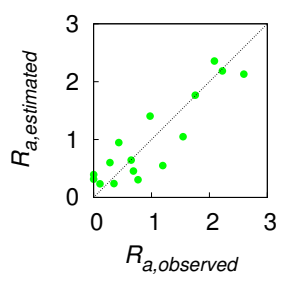

$\mathrm{r}^{2}=0.80$

$\mathrm{AlC}_{\mathrm{C}}=-21.2$

$\mathrm{p}<0.001$
BGD

7, 9137-9173, 2010

\section{Spatial and seasonal variability of soil respiration}

N. Prolingheuer et al.

\section{Title Page}

\section{Abstract}

Introduction

Conclusions

References

Tables

Figures

Fig. 3. Regression models of soil respiration related to soil temperature and water content. (a) Total soil respiration $R_{\mathrm{s}}$ related to soil temperature $T_{\mathrm{s}}$ and water content $\theta_{\mathrm{s}}$ in $6 \mathrm{~cm}$ depth, (b) heterotrophic soil respiration $\left(R_{\mathrm{h}}\right)$ related to soil temperature $T_{\mathrm{h}}$ and water content $\theta_{\mathrm{h}}$ in $6 \mathrm{~cm}$ depth, (c) autotrophic respiration $R_{\mathrm{a}}$ related to soil temperature $T_{\mathrm{s}}$ and water content $\theta_{\mathrm{s}}$ in $6 \mathrm{~cm}$ depth. $r^{2}$ : coefficient of determination, RMSE: root mean square error, $\mathrm{AIC}_{\mathrm{c}}$ : corrected Akaike Information Criterion, $p$ : $p$-value. 


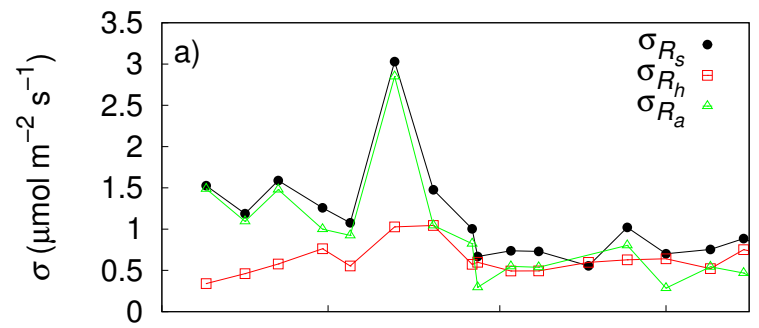

BGD

7, 9137-9173, 2010

Spatial and seasonal variability of soil respiration

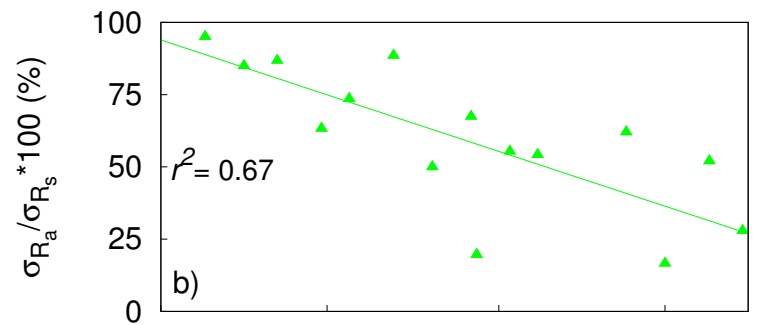

N. Prolingheuer et al.

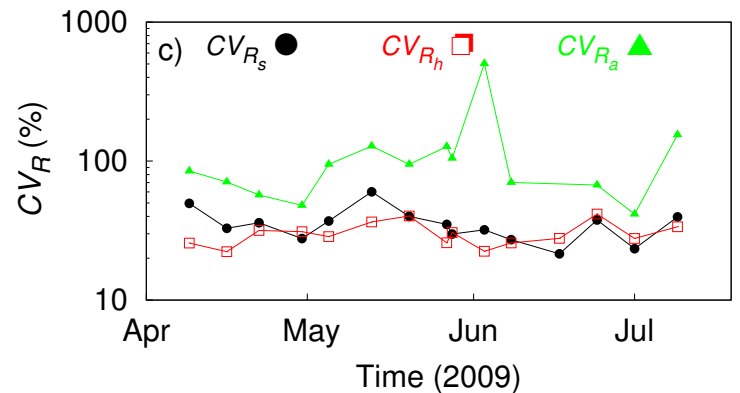

\section{Title Page}

Abstract

Introduction

Conclusions

References

Tables

Figures

14

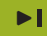

4

Back

Close

\section{Full Screen / Esc}

Printer-friendly Version

Fig. 4. Standard deviation of total $\left(\sigma_{R_{s}}\right)$, heterotrophic $\left(\sigma_{R_{\mathrm{f}}}\right)$ and autotrophic respiration $\left(\sigma_{R_{\mathrm{a}}},(\mathbf{a})\right)$, the autotrophic contribution to the spatial variations of total soil respiration (b) and (c) coefficient of variation (CV) of total $\left(\mathrm{CV}_{R_{\mathrm{s}}}\right)$, heterotrophic $\left(\mathrm{CV}_{R_{h}}\right)$ and autotrophic soil respiration $\left(\mathrm{CV}_{R_{a}}\right) ; r^{2}$ : coefficient of determination of linear regression in (b). 

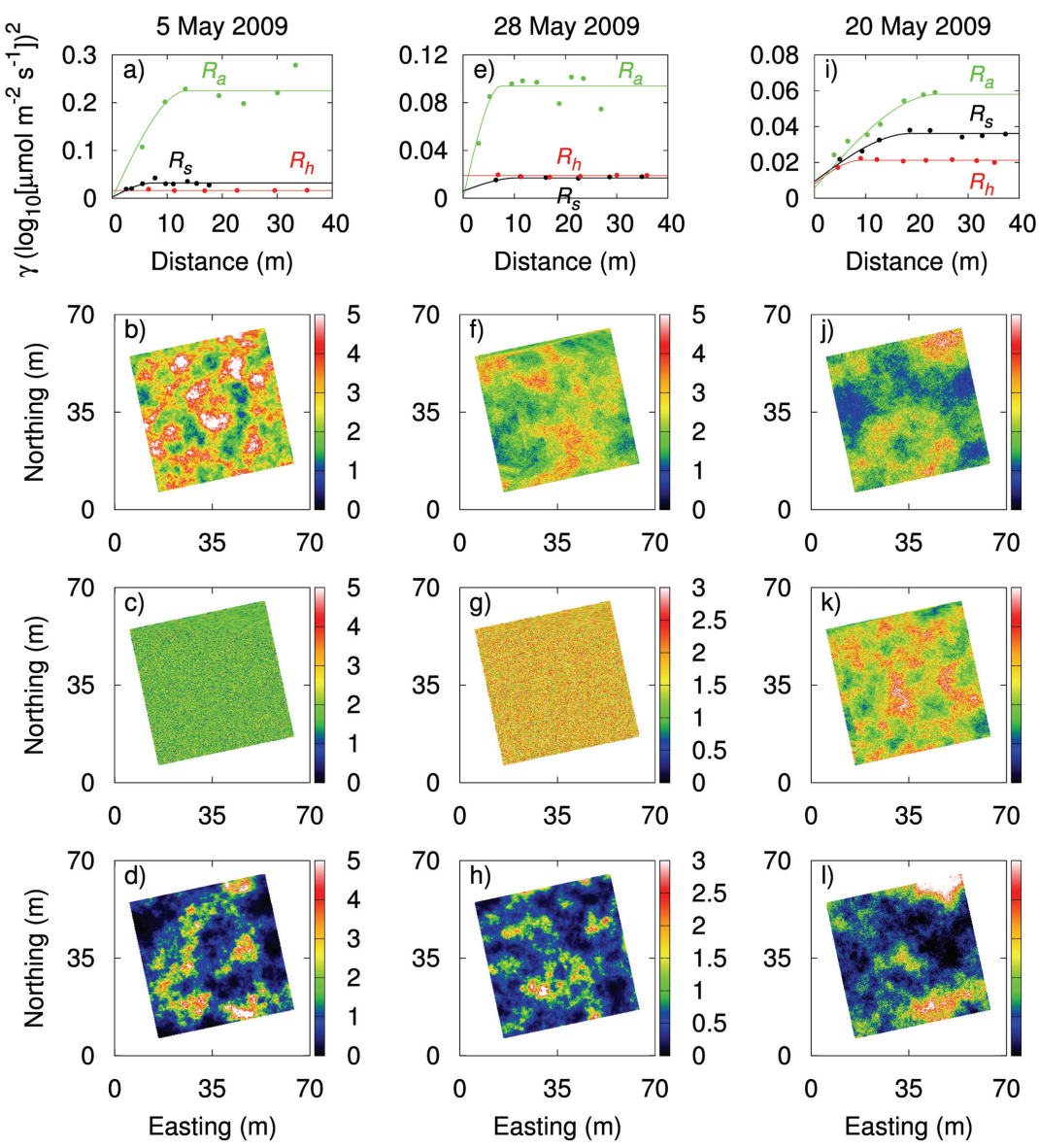

BGD

7, 9137-9173, 2010

Spatial and seasonal variability of soil respiration

N. Prolingheuer et al.

\section{Title Page}

\section{Abstract}

Introduction



Conclusions

References

Tables

Figures

14

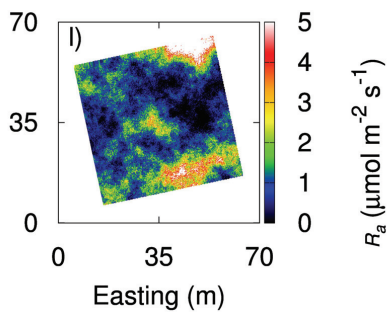

4

\section{Back}

Close

\section{Full Screen / Esc}

Printer-friendly Version

Interactive Discussion respiration $\left(R_{a}\right)$ in winter wheat on 5 May $2009(\mathbf{a}-\mathbf{d}), 28$ May $2009(\mathbf{e}-\mathbf{h})$ and 20 May 2009 (i-I). Spatial patterns were calculated using conditional sequential Gaussian simulation. 


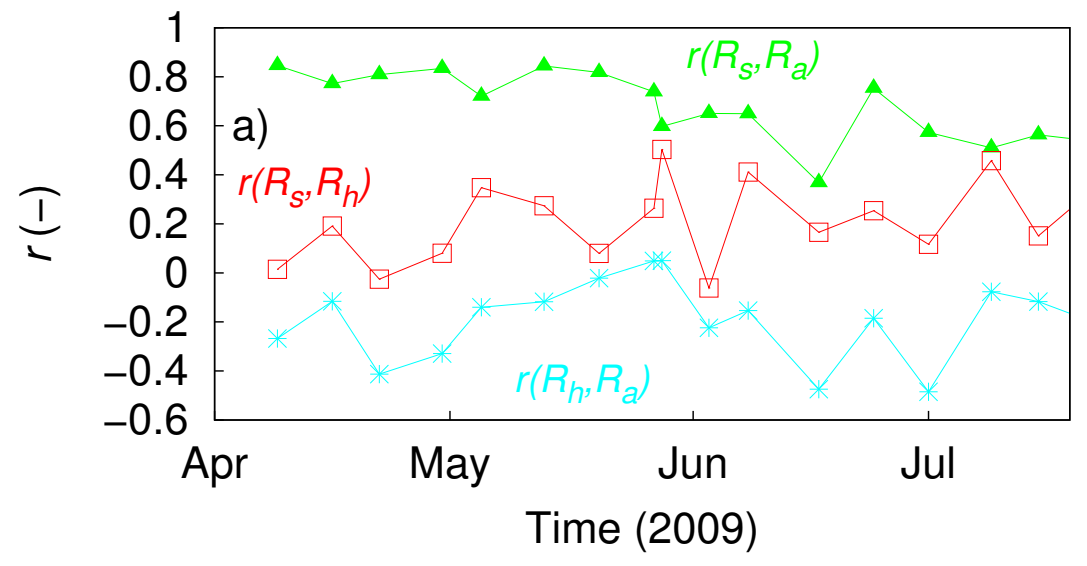

BGD

7, 9137-9173, 2010

Spatial and seasonal variability of soil respiration

N. Prolingheuer et al.



Title Page

Abstract

Introduction

Conclusions

References

Tables

Figures

14



Back

Close

\section{Full Screen / Esc}

Printer-friendly Version

Fig. 6. Spatial correlation of total $\left(R_{\mathrm{s}}\right)$, heterotrophic $\left(R_{\mathrm{h}}\right)$ and autotrophic soil respiration $\left(R_{\mathrm{a}}\right)$ among each other. (a) Spatial correlation of $R_{\mathrm{s}}$ with $R_{\mathrm{h}}$ and $R_{\mathrm{a}}$, respectively, and $R_{\mathrm{h}}$ with $R_{\mathrm{a}}$ during the season, (b) cross-variograms of $R_{\mathrm{s}}$ with $R_{\mathrm{h}}$ and $R_{\mathrm{a}}$, respectively, on 5 May 2009.

Interactive Discussion 